\title{
Review \\ Histone Modification in NSCLC: Molecular Mechanisms and Therapeutic Targets
}

\author{
Khuloud Bajbouj ${ }^{1,2}\left(\mathbb{D}\right.$, Abeer Al-Ali ${ }^{2}$, Rakhee K. Ramakrishnan ${ }^{1,2}\left(\mathbb{D}\right.$, Maha Saber-Ayad ${ }^{1,2,3, *(\mathbb{C})}$ and \\ Qutayba Hamid 1,2,4 (D) \\ 1 College of Medicine, University of Sharjah, Sharjah 27272, United Arab Emirates; \\ kbajbouj@sharjah.ac.ae (K.B.); rramakrishnan@sharjah.ac.ae (R.K.R.); qalheialy@sharjah.ac.ae (Q.H.) \\ 2 Sharjah Institute for Medical Research, University of Sharjah, Sharjah 27272, United Arab Emirates; \\ U20106060@sharjah.ac.ae \\ 3 Faculty of Medicine, Cairo University, Cairo 11559, Egypt \\ 4 Meakins-Christie Laboratories, Research Institute of the McGill University Health Center, \\ Montreal, QC H4A 3J1, Canada \\ * Correspondence: msaber@sharjah.ac.ae; Tel.: +971-6-505-7219; Fax: +971-5-558-5879
}

check for updates

Citation: Bajbouj, K.; Al-Ali, A.; Ramakrishnan, R.K.; Saber-Ayad, M.; Hamid, Q. Histone Modification in NSCLC: Molecular Mechanisms and Therapeutic Targets. Int. J. Mol. Sci. 2021, 22, 11701. https://doi.org/ 10.3390/ijms222111701

Academic Editors:

Federico Cappuzzo, Serena Ceddia and Lorenza Landi

Received: 10 October 2021

Accepted: 25 October 2021

Published: 28 October 2021

Publisher's Note: MDPI stays neutral with regard to jurisdictional claims in published maps and institutional affiliations.

Copyright: (c) 2021 by the authors. Licensee MDPI, Basel, Switzerland. This article is an open access article distributed under the terms and conditions of the Creative Commons Attribution (CC BY) license (https:/ / creativecommons.org/licenses/by/ $4.0 /)$.

\begin{abstract}
Lung cancer is the leading cause of cancer mortality in both genders, with non-small cell lung cancer (NSCLC) accounting for about $85 \%$ of all lung cancers. At the time of diagnosis, the tumour is usually locally advanced or metastatic, shaping a poor disease outcome. NSCLC includes adenocarcinoma, squamous cell carcinoma, and large cell lung carcinoma. Searching for novel therapeutic targets is mandated due to the modest effect of platinum-based therapy as well as the targeted therapies developed in the last decade. The latter is mainly due to the lack of mutation detection in around half of all NSCLC cases. New therapeutic modalities are also required to enhance the effect of immunotherapy in NSCLC. Identifying the molecular signature of NSCLC subtypes, including genetics and epigenetic variation, is crucial for selecting the appropriate therapy or combination of therapies. Epigenetic dysregulation has a key role in the tumourigenicity, tumour heterogeneity, and tumour resistance to conventional anti-cancer therapy. Epigenomic modulation is a potential therapeutic strategy in NSCLC that was suggested a long time ago and recently starting to attract further attention. Histone acetylation and deacetylation are the most frequently studied patterns of epigenetic modification. Several histone deacetylase (HDAC) inhibitors (HDIs), such as vorinostat and panobinostat, have shown promise in preclinical and clinical investigations on NSCLC. However, further research on HDIs in NSCLC is needed to assess their anti-tumour impact. Another modification, histone methylation, is one of the most well recognized patterns of histone modification. It can either promote or inhibit transcription at different gene loci, thus playing a rather complex role in lung cancer. Some histone methylation modifiers have demonstrated altered activities, suggesting their oncogenic or tumour-suppressive roles. In this review, patterns of histone modifications in NSCLC will be discussed, focusing on the molecular mechanisms of epigenetic modifications in tumour progression and metastasis, as well as in developing drug resistance. Then, we will explore the therapeutic targets emerging from studying the NSCLC epigenome, referring to the completed and ongoing clinical trials on those medications.
\end{abstract}

Keywords: histone deacetylase; demethylase; methyltransferase; KDM; LSD; tumour suppressor genes; vorinostat

\section{Introduction}

Lung cancer is the most common malignancy worldwide, with the highest mortality among all cancers. By 2030, it is estimated to kill 10 million people per year worldwide [1]. There are four fundamental histological types, which account for approximately $95 \%$ of all lung cancers. These include squamous cell carcinoma (SCC) (20-35\%), adenocarcinoma (ADC) (30-50\%), and large cell cancer (LCC) (9\%), all of which belong to non-small cell lung 
carcinoma (NSCLC) (80-84\%). Other NSCLC subtypes, such as carcinoma of adenosquamous and sarcomatoid subtypes, are much less common. Small cell carcinoma (SCLC) accounts for only $16-20 \%$ of all lung cancer [2]. Details on the pathology and classification of lung cancer were covered in several review articles [2,3]. Depending on the stage of the tumour, the five-year survival after lung cancer surgery ranges between 10 and $70 \%$ [4]. NSCLC in older age groups usually carries the lowest cancer-specific survival and the worst overall survival (OS) [5]. However, thanks to therapeutic advances, the two-year relative survival rate for NSCLC increased from $34 \%$ (in 2010) to $42 \%$ (in 2015), with an absolute rise of $5 \%$ to $6 \%$ for every stage of diagnosis [6]. While cigarette smoking is by far the leading cause of lung cancer in both men and women, other etiologic factors such as second-hand smoking, radon, asbestos, or heavy metals also play a role [7]. Interestingly, lung exposure to cigarette smoke may affect histone modifications. In addition, nickel, chromate, and arsenite in tobacco induce histone H3K9 dimethylation and stimulate histone deacetylation $[8,9]$.

In the current review, we will first give an overview on the initiation and signalling pathways in NSCLC, focusing on the role of histone modification. The patterns and mechanisms of histone modification will be discussed. Then, the role of epigenetic modifying agents in NSCLC will be described in vitro, in pre-clinical trials, and then in clinical trials. We will also discuss the different combination therapy options in the treatment of NSCLC.

\section{Lung Cancer Initiation and Signalling Pathways}

Rather than capitalizing on specific factors, genetic abnormalities correlated to lung cancer risk should be considered in the context of signalling pathways with distorted main functions. Several major pathways with key components have dysregulated functions in lung cancer, with emerging significance in terms of targeted therapy. Aberrations in the growth-stimulation signalling pathways or tumour suppressor gene (TSG) pathways significantly contribute to lung cancer development [10]. Oncogene mutations cause tumour cells to become "addicted" to their aberrant functions. Notably, the TSGs are linked to environmental factors such as smoking and air pollution [11].

Exposure to cigarette smoke can cause an inflammatory response in a smokers' airways, releasing several inflammatory mediators and growth factors (e.g., transforming growth factor $\beta$ (TGF- $\beta$ ), epidermal growth factor receptor (EGFR), interleukin-1 (IL-1), IL-8, and granulocyte colony stimulating factor (G-CSF)). Such inflammation can last for decades after the cessation of smoking, leading to pathological and neoplastic changes [12]. Interestingly, KRAS mutations are increased in smokers. On the contrary, EGFR and HER2 mutations are increased in non-smokers. Such an observation adds to the findings that lung cancer in smokers and non-smokers arises via distinct pathogenic pathways [10]. Hazardous air pollutants or chemicals released into the environment may have a negative impact on human health. Gases (including sulphur dioxide $\left(\mathrm{SO}_{2}\right)$, nitrogen oxides (NOx), carbon monoxide (CO)), heavy metals, and particulate matter (PM) are all air pollutants that have a deleterious impact, particularly on the respiratory system. According to the International Agency for Research on Cancer (IARC), both outdoor and PM air pollutants are Group 1 carcinogens [13].

\section{Epigenetics in Lung Cancer}

Cancer is considered a genetic disease. Mutations are one of the cancer hallmarks. However, there is also mounting evidence that the epigenetic modification of gene expression (including the mutant genes) plays a key role in carcinogenesis of the lung and other cancers [14]. Epigenetics refer to heritable chromatin modifications that impact gene expression (among a myriad of DNA-dependent processes) without a direct effect on the coding sequence of the DNA [15]. Epigenetic regulation of gene expression occurs at three levels: DNA (DNA methylation), protein (histone/nucleosome modification), and non-coding RNA (ncRNAs). Amongst the major epigenetic regulatory mechanisms, DNA methylation is perhaps the most studied, and it is responsible for gene silencing. Intriguingly, histone 
proteins can be modified in a variety of ways, including acetylation, methylation, and phosphorylation, in addition to ubiquitylation and sumoylation. Histone covalent modifications, opposed to DNA methylation, not only silence the expression of specific genes, but rather promote transcription. Out beyond the classical epigenetic mechanisms, ncRNAs, particularly microRNAs (miRNA) and long ncRNAs (lncRNAs), are also recognized as epigenetic modifiers [16]. Mutations in epigenetic regulatory mechanisms and epigenetic pattern disruptions have been linked to a variety of tumour types, which include lung cancer via TSG silencing and oncogene activation. Chemotherapy resistance is also linked to epigenetic changes [15].

Recent epigenetic advances have improved our knowledge of the basic mechanisms of carcinogenesis. Changes in the epigenetic factors lead to alterations in the expression of key oncogenes and TSGs [17]. Several epigenetic processes in lung cancer have an impact on cancer hallmarks, such as proliferation, invasion, metastasis, apoptosis, and regulations of cell cycle [18]. Further to cancer hallmarks, epigenetic deregulation in lung cancer affects numerous impactful signalling pathways, including the ERK family, NF-kB signalling pathway, and Hedgehog signalling pathway [17]. Concurrently, epigenetic marks shed light on the identification of potential cancer biomarkers for early screening, monitoring, and therapeutic approaches of NSCLC.

In addition to genetic changes occurring in lung cancer, epigenetic modifications also impact various components of chromatin modifying events such as histone modifications, DNA methylation, and microRNA regulation [15]. Histone deacetylases (HDACs) are frequently overexpressed in cancers and have emerged as promising therapeutic targets [19]. HDAC overexpression can result in TSG silencing and abnormal transcription as a result of the modified expression and/or mutations of genes encoding histone acetyltransferase (HAT) or HDAC enzymes or their binding congeners, which are directly connected to carcinogenesis [20] (Figure 1).

\subsection{Histone Modifications}

The DNA is packed as chromatin in eukaryotic cells, with nucleosomes serving as functional units. Every other nucleosome is made up of an octamer of four core histones (H3, H4, H2A, and H2B) rolled up in 147 base pairs of DNA [18]. The nucleosome's core is formed by the globular regions of histones, while the $\mathrm{N}$-terminal tails protrude from the nucleosomes and are enhanced with a diverse array of posttranslational modifications (PTMs). Histone tails are altered by a large group of non-histone chromatin-associated proteins known as chromatin-modifying enzymes. These enzymes reside in cells as multicomponent protein complexes that are regularly recruited to chromatin in association with DNA-bound transcription factors [21]. Numerous covalent PTMs in histones and associated regions of DNA play critical roles in genomic functions by binding specific transcription factors and co-activators, altering the structural properties of chromatin [22].

Based on their functions, chromatin modification enzymes are divided into four groups: acetylation HATs, deacetylation by HDACs, methylation by HMTs, and demethylation by HDMs (Figure 1). The generated PTMs could function concertedly or alone to promote activation or suppression of chromatin-mediated gene expression of inflammatory cytokines, cell cycle arrest, senescence, apoptosis, growth factors, and antioxidants, in addition to TSGs associated with lung cancer [23]. 

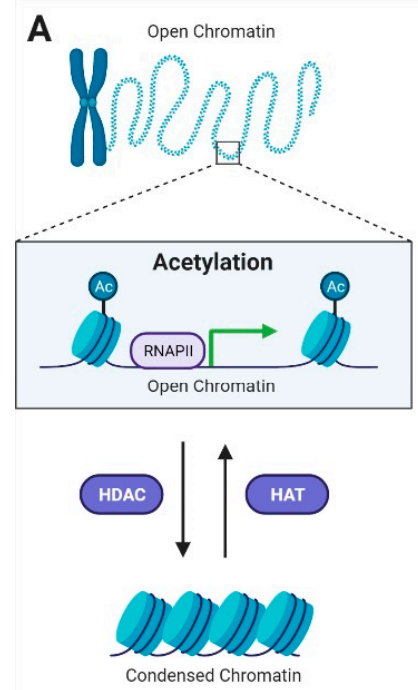

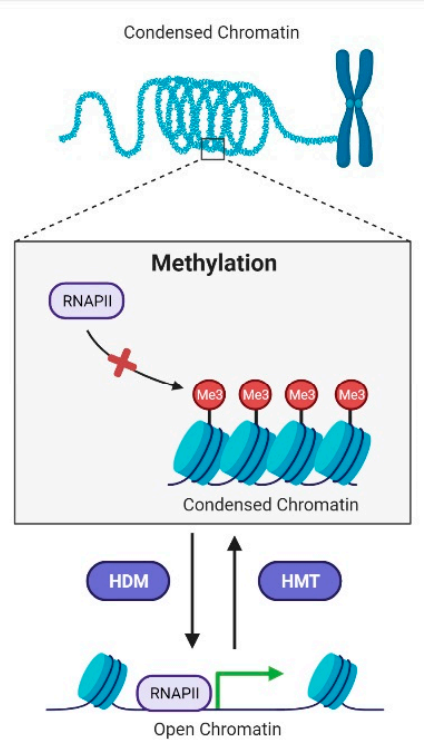

B

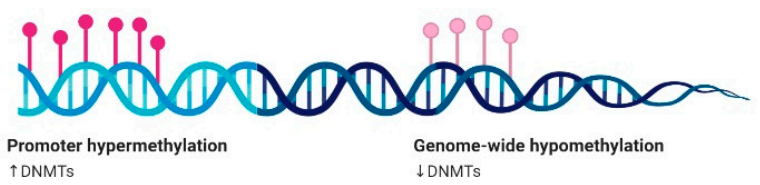
Promoter hypermethylation
$\uparrow$ DNMTs $\downarrow$ DNMTs

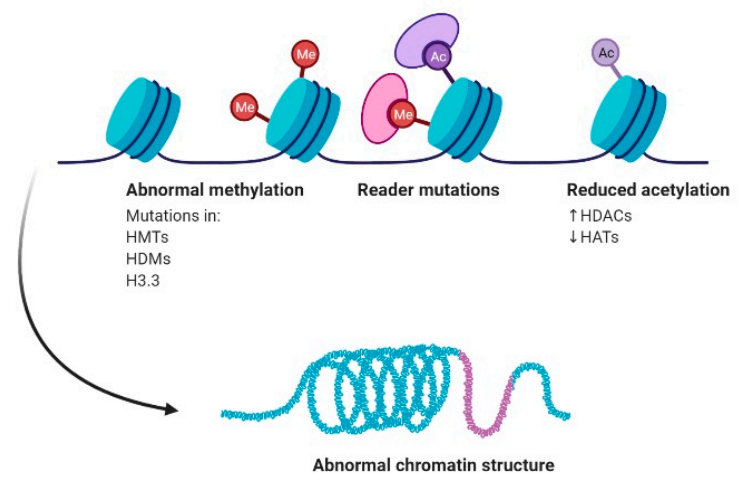

Figure 1. Epigenetic regulatory mechanisms linked to lung cancer. (A) Acetylation of histones reduces its positive charge, thereby relaxing the tightly coiled negatively charged DNA wrapped around them. The open chromatin structure enables access to the transcriptional machinery (including RNA polymerase and transcriptional factors), resulting in active gene transcription. Conversely, methylation of histones is generally associated with a condensed chromatin structure, which prevents access to the transcriptional machinery repressing gene transcription. While histone acetyltransferases (HATs) introduce acetyl groups onto lysine residues on histones, histone deacetylases (HDACs) carry out deacetylation of histones. Similarly, histone methyltransferases (HMTs) promote the addition of mono-, di-, or tri-methyl groups at arginine and/or lysine residues on histones, while histone demethylases (HDMs) are responsible for removing these methyl groups. (B) Cancer cells display hypermethylation of multiple promoter $\mathrm{CpG}$ islands as well as a genome-wide loss of DNA methylation at sporadic CpGs. Methyl-binding proteins are further capable of recruiting HDACs. The overexpression of HMTs and HDACs thus results in reduced chromatin access and silencing of TSG. This abnormal epigenetic activity paves the way to lung cancer development and progression.

\subsection{Histone Modifications Cross Talk}

Histones can be influenced by a myriad of PTMs, resulting in a plethora of combinatorial patterns. These can arise on any of the four core histones and can even differ between tails of the same histone within a single nucleosome or nucleosomes. Identifying which essential modifications influence tumourigenesis and which are bystanders is a critical complicated goal, since various interactions between PTMs occur (modification cross talk). In some cases, histone PTMs can function as exclusion marks, restricting the appearance of other marks [22]. Histone lysine acetylation and arginine methylation can both co-localize and initiate other methyltransferase actions. Furthermore, histone methylation and phosphorylation can regulate each other. An important example is when an adjacent phosphorylation event disrupts chromodomain recognition of a methylated lysine. Fundamentally, the challenge of definitively linking changes in primary chromatin to cancer and then identifying how cross talk contributes to cancer are critical questions to be addressed. Intriguingly, histone PTM around the DNA damage site is crucial in the process of DNA repair [21].

\subsection{Histone Acetylation/Deacetylation}

A number of histone modifiers and chromatin-bound proteins regulate transcription activation and repression. At the stable processes of the cell, an equilibrium between specific modifications and modifiers is sustained to retain chromatin structure, perform the precise gene expression program, and control the biological output (Figure 1). When the balance is changed, cell phenotypes can be altered, setting the stage for disease onset 
and progression [24]. Studying the main regulators of histone modifications will thus aid in the development of chemical probes to preserve homeostasis and regain the balanced state of the cell. Chromosomes are structured into coiled chromatin fibers, made up of units (nucleosomes), which are a central core of histone proteins, around which the DNA is coiled [25]. This condensed structure renders the DNA transcriptionally inactive via decreasing the interaction between the DNA and its transcription and replication proteins. Inversely, chromatin composition can be reversibly altered by uncoiling to grant access to DNA-binding factors and activate transcription. Histone acetylation is a major remodelling process, in which HATs introduce acetyl groups to lysine residues on histone $\mathrm{N}$-terminal tails that protrude from the nucleosome complex [21]. Histone acetylation results in a loss of positive charge, decreased affinity between histones and DNA, and resultant uncoiling to give access to RNA polymerase and transcription factors. HDACs, on the other hand, eliminate acetyl groups and operate as a transcriptional suppressor [15].

Histone deacetylation is modulated by DNA methylation via repressor protein binding to methylated CpGs in DNA. As a result, PTMs of histones via acetylation and deacetylation are a main determinant of transcription regulation, impacting gene expression. At least 18 human HDAC enzymes have been identified [26]. Based on their homology to yeast HDACs, subcellular localization, tissue specificity, and enzymatic activities, they are categorized into four classes (I, II, III, and IV) [27]. The classical HDAC family is made up of class I (HDAC1, 2, 3, and 8) and class II (HDAC4, 5, 6, 7, 9, and 10) HDACs, with HDAC11 exhibiting interlaced properties. Class I HDACs are found in the nucleus, while class II HDACs travel to and from the nucleus. HDACs are actively engaged in a variety of biological processes, such as cell cycling, proliferation, differentiation, cell death, DNA replication, mitosis, and cancer development [26]. Interestingly, HDAC inhibition was recognized through empirical screening of some agents that were shown to induce cancer cell differentiation. These agents, such as butyrate, trichostatin A (TSA), and suberoylanilide hydroxamic acid (SAHA) (vorinostat) were discovered to have HDAC inhibitory action [28]. Three decades ago, Breslow et al. described SAHA to arrest the growth of murine erythroleukemia cells at low concentrations, positioning it as a lead HDAC inhibitor (HDI) [29].

The HDIs have the ability to kill cancer cells through apoptosis, autophagy, necrosis, reactive oxygen species (ROS), cell cycle arrest, tumour angiogenesis suppression, and immunomodulatory effects. They stimulate the death receptor, as well as intrinsic mitochondrial pathways, reducing the overall apoptotic threshold of tumour cells. They increase the expression of death receptor pathway-related pro-apoptotic genes (TRAIL and DR5) and/or the intrinsic apoptotic pathway (Bax, Bak, and APAF1). On the other hand, HDIs decrease the expression of pro-survival genes (BCL-2 and XIAP). They also selectively induce BH3-only proteins, resulting in the activation of the intrinsic apoptotic pathway [30]. Aside from their direct anti-cancer effects, HDIs boost the immune system by increasing the expression of the major histocompatibility complex (MHC) class I and II proteins, as well as costimulatory and/or adhesion molecules such as CD80, CD86, human leukocyte antigen (HLA)-DR, HLA-ABC, and intracellular adhesion molecule-1 (ICAM-1,28). HDIs could also improve immune responses by modifying immune cell activities, either directly or indirectly via the cytokine secretion modulation [28]. Both in vitro and in vivo studies have showed that HDIs suppress the growth of a wide spectrum of cancer cells, including those of lung cancer [15].

\subsection{Histone Methylation}

Two important enzyme groups control histone methylation: methyltransferases and demethylases. Histone methylation mainly involves the lysine $(K)$ and arginine $(R)$ residues on the N-terminal of the histone tail [31]. Histone methylation can promote or inhibit various gene transcriptions, denoting an intricate function in cancer, based on the location and methylation level of the target amino acid. Histone $\mathrm{H} 3$ has five lysines amenable for modification by methylation (K4, K9, K27, K36, and K79). Similarly, K20 of histone H4 
undergoes methylation by a specific histone lysine methyltransferase. H3K4 and H3K36 methylation can activate gene transcription, whereas H3K9, H3K27, H3K79, and H4K20 methylation can suppress gene transcription [32]. Abnormalities in histone methylation are closely linked to various cancers.

The role of histone lysine methyltransferases (KMTs) is to add methyl groups. Thus, they function as 'writers' of the histone code, whereas histone lysine demethylases (KDMs) are known as 'erasers' of methyl groups (Figure 2) [33]. Catalyzed by methyltransferase, methylation leads to adding one, two, or three methyl groups. The trivalent methylation is known as hypermethylation [34]. For instance, KDM1A (also known as lysine specific demethylase, or LSD1) targets $\mathrm{H} 3 \mathrm{~K} 4 \mathrm{me} 2 / \mathrm{me} 1$ and $\mathrm{H} 3 \mathrm{~K} 9 \mathrm{me} 2 / \mathrm{me} 1$ and is overexpressed in NSCLC [35]. EZH2 mediates trivalent methylation of lysine 27 on histone H3 (H3K27me3), thus causing condensation of chromatin and repression of TSG transcription [36]. SMYD3 targets H3K36 and plays a pivotal role in the regulation of oncogenic Ras signalling in NSCLC (and also in pancreatic ductal adenocarcinoma) [37]. In a bioinformatics-based study in 2019, Li et al. analyzed gene variants, mRNA expression of histone methyltransferases, and demethylases in NSCLC in relation to the patients' data. They suggested that some genes related to histone methylation may have potential prognostic and/or therapeutic value, awaiting further biological validation [38].

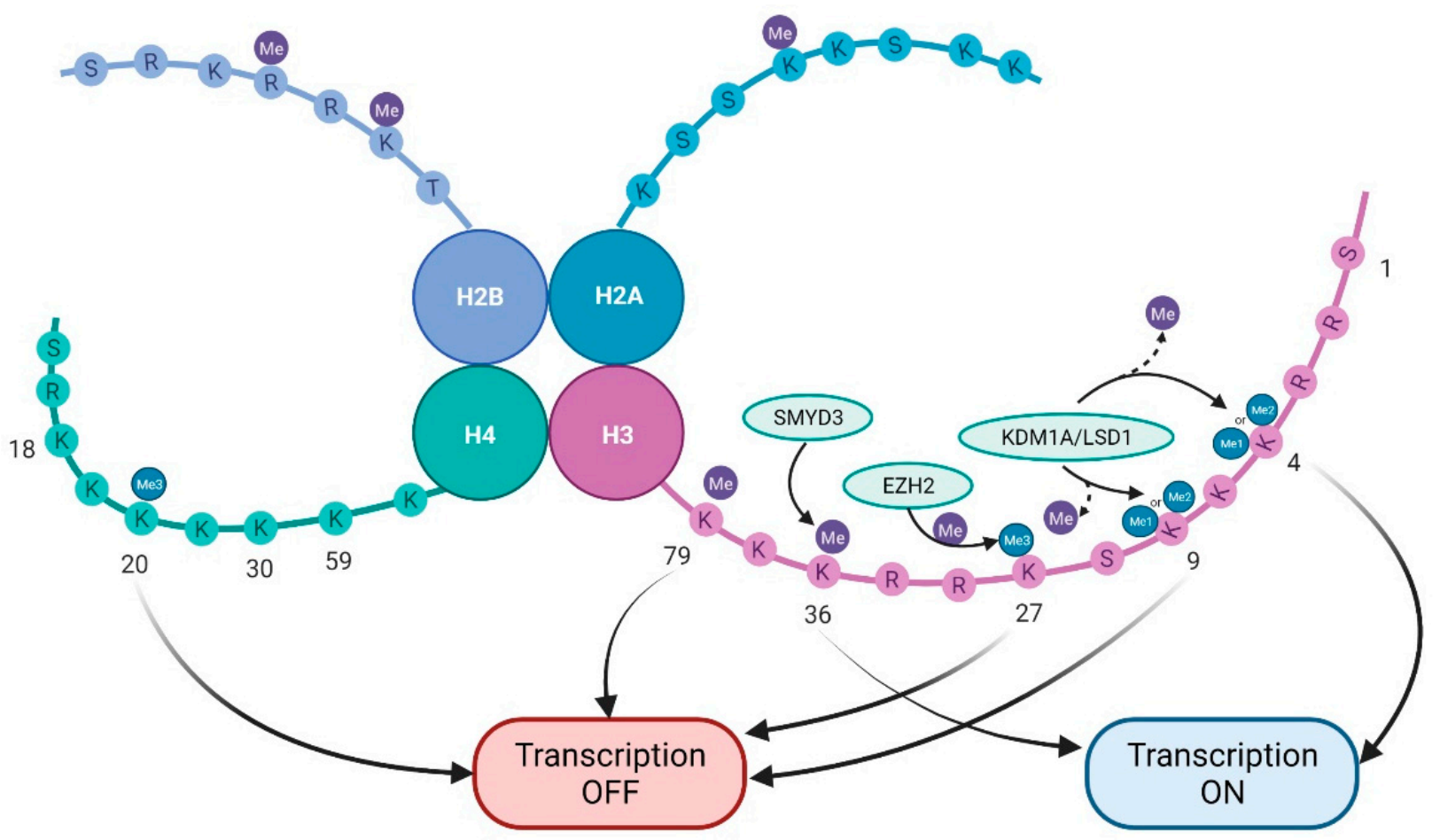

Figure 2. Histone methylation landscape in lung cancer. The lysines K4, K9, K27, K36, and K79 on histone H3 and K20 of histone $\mathrm{H} 4$ are amenable for modification by methylation. While H3K4 and H3K36 methylation activate gene transcription, H3K9, H3K27, H3K79, and H4K20 methylation suppress gene transcription. Histone lysine methyltransferases (KMTs) add methyl groups to histones and are 'writers' of the histone code. SMYD3 targets H3K36, and EZH2 mediates trivalent methylation of H3K27, causing chromatin condensation and subsequent repression of TSG transcription. On the other hand, demethylases, such as KDMs, are known as 'erasers' of methyl groups, and consequently, KDM1A/LSD1 targets H3K4me2/me1 and H3K9me2/me1.

\subsection{The Histone Code of Lung Cancer}

Histone deacetylases and histone methyltransferases are linked to methyl-CpG binding proteins and DNA methyltransferases. Human cancers have a tremendous overall loss of DNA methylation, but they develop specialized patterns of hypermethylation of partic- 
ular promoters. DNA methylation tends to occur alongside other epigenetic modifications. The acetylation and methylation condition of particular lysine residues within the tail of nucleosome core histones play a significant role in modulating chromatin packaging, nuclear structure, gene expression, and genomic stability [39]. The process of promoter CpG island hypermethylation of transcriptionally repressed TSGs is affiliated with a specific combination of histone markers in lung cancer cells. Examples include deacetylation of histones $\mathrm{H} 3$ and $\mathrm{H} 4$, the loss of histone $\mathrm{H} 3$ lysine 4 trimethylation, and the gain of $\mathrm{H} 3 \mathrm{~K} 9$ and H3K27 trimethylation.

The epigenetic landscape of cancer cells that are fundamentally distorted in appearance, when contrasted to normal cells, has demonstrated the effect of histone code alterations in lung cancer tumourigenesis and prognosis. In NSCLC and pre-invasive bronchial dysplastic lesions, there is an increased acetylation of $\mathrm{H} 4 \mathrm{~K} 5 / \mathrm{H} 4 \mathrm{~K} 8$ and loss of trimethylation of H4K20. H4K20 trimethylation loss was found to be associated with a subpopulation of early stage I ADC with shortened survival [40]. Furthermore, H2 and H3 acetylation and trimethylation states in NSCLC enable the identification of prognostic markers. The prognostic value of epigenetic alterations involving multiple histones, particularly $\mathrm{H} 2 \mathrm{~A}$ (H2AK5ac) and H3 (H3K4me2, H3K9ac), was higher in early NSCLC, and evaluating these changes may aid in the selection of early-stage NSCLC patients for adjuvant therapy [41]. Likewise, H3K4me2 and H3K18ac cellular levels were relatively low, and the identified histone modification trends were independent predictors of prognosis in ADC [42]. These findings strongly suggest that reduced cellular levels of specific histone modifications are likely to predict a shorter survival time.

Intriguingly, histone modification levels positively correlated with one another; loss of one histone modification generally correlated with loss of other modifications within a patient [42]. Furthermore, demethylated DNA repetitious elements in cancer DNA may also be demethylated and/or deacetylated on their associated histones. The biological consequences of these histone modifications at repeated elements are unknown, but they are likely affiliated with a much more aggressive phenotype [42]. In general, a higher frequency of cancer cells, with reduced global levels of histone modifications, signifies a poorer clinical outcome, i.e., a higher risk of tumour relapse and/or a shorter survival time in lung cancer [43]. The modalities influencing histone alterations are still being investigated and may be ascribed to incorrect targeting, distorted expression, and/or activity of histone-modifying enzymes due to genetic mutations, expression shifts, and/or posttranslational control [44]. Modern innovations employing genome-wide cancer epigenetics methodologies have revealed that global changes in histone modification patterns correlate with DNA methylation in lung cancer [45].

\subsection{Histone Deacetylase Expression in Lung Cancer}

HDAC expression in lung cancer tissue samples has been investigated in a number of studies. In a study of 102 NSCLC resection specimens, HDAC1 mRNA and protein expression were higher in patients with stages III and IV lung cancer, as opposed to stage I or II. There was no significant difference in mRNA expression between tumour and non-tumour lung tissue [46]. The mRNA expression of HDAC1 to 8 and 10 was linked with prognosis in a study of 72 NSCLC specimens [47]. Low expression of class II HDACs, particularly HDAC10, was linked with a worse prognosis after surgery. HDAC3 protein expression was observed to be upregulated in SCC specimens employing antibody arrays and was verified by immunoblot analysis [48]. These preliminary studies suggest that HDACs suppress pivotal gene pathways implicated in protection against lung cancer.

\section{Lung Cancer Therapeutics}

Surgery, chemotherapy (platinum-based regimens), radiotherapy, combined chemoradiotherapy, and targeted therapy, either alone or in combination, are conventional therapies for lung cancer. Surgery to extract the tumour and nearby lymph nodes is the most consistent and effective treatment in the early disease. When surgery is not an ideal solution, 
radiotherapy and/or chemotherapy may be recommended [49]. As previously mentioned, the two-year relative survival rate for NSCLC has gained an absolute rise of 5-6\% over 5 years, thanks to advances in therapeutic modalities for late stages, including targeted EGFR tyrosine kinase inhibitors (TKIs) and, to a lesser extent, immunotherapy [6]. The survival improvement in earlier stages of the disease is likely due to the implementation of advanced surgical procedures (e.g., video-assisted thoracoscopic surgery) [50].

Epigenetically active drugs may aid two groups of lung cancer patients in particular: those who are not suitable for aggressive chemotherapy and those with high-risk NSCLC. The first group, i.e., patients who are ineligible for chemotherapy, could still be qualified for epigenetic therapy, which typically has a safer profile. Epigenetic therapies, instead of being cytotoxic like traditional chemotherapeutics, are believed to promote apoptosis and/or differentiation by overturning aberrant gene silencing or activation. In theory, this might eradicate only cancer cells while leaving normal cells alone, leading to fewer and less severe side effects [51]. The second group consists of high-risk NSCLC patients, defined as those with a shortened relapse-free survival (RFS) who appear to be predisposed to relevant epigenetic alterations, such as abnormal DNA methylation of HIST1H4F, PCDHGB6, NPBWR1, ALX1, and HOXA9 [52].

\subsection{Histone Modifications in Lung Therapeutics \\ 3.1.1. Histone Deacetylases Inhibitors in Preclinical Studies}

For decades, numerous HDIs have been produced and studied for their possibility as anti-cancer agents, ever since the identification that TSA inhibited HDACs and triggered differentiation and cell cycle arrest in mammalian cells [53]. There are several classes of HDIs, including hydroxamate, cyclic peptide, aliphatic acid, and benzamide classes [26]. Aiming at a nuclear-specific class I HDAC could have a more specific effect on histone acetylation with minimal side effects on non-histone cytoplasmic proteins. HDI treatment of cancer cells induced G1-phase cell cycle arrest by activating p21 and suppressing cyclin expression. Such agents have demonstrated the ability to activate both extrinsic and intrinsic apoptotic pathways by changing the expression of death receptors and ligands, in addition to the balance of major intracellular pro-apoptotic and antiapoptotic regulators [54,55]. Preclinical studies in NSCLC cell lines have illustrated that initiation of apoptosis in response to HDIs also entails checkpoint kinase 1 downregulation [56]. Furthermore, HDIs also cause DNA damage, downregulate the expression of DNA repair genes, repress proangiogenic and matrix remodelling genes, and disrupt glucose metabolism by targeting the glucose transporter 1 and hexokinase 1. Ultimately, HDIs may regulate cancer cell immunogenicity by upregulating molecules participating in T-cell and natural killer cell activation, such as MHC class I and II, CD80/CD86, and MHC class I chain-related molecules (MICA/MICB) [55].

Miyanaga et al. tested 16 NSCLC cell lines with HDAC inhibitors, including TSA and vorinostat, and found that both had anti-tumour activity in 50\% of the NSCLC cell lines [28]. As a result, HDIs may exert their anti-cancer action, at least in part, by decreasing tumour cell responsiveness to TNF-mediated activation of the NF- $\mathrm{kB}$ pathway, as TNF-receptor-1 expression and TNF-mediated NF- $\mathrm{kB}$ nuclear translocation were all reduced in HDI-treated NSCLC cells [57].

Several chromatin remodelling studies suggest that HDIs have biological implications in lung cancer cell lines. TSA inhibited telomerase activity albeit with no effect in NSCLC cell lines [58]. Treatment with the HDI sodium butyrate caused global histone hyperacetylation and chromatin decondensation in the A549 cell line [59]. TSA treatment of the H69 SCLC cell line resulted in a chromatin decondensation pattern of nuclear texture [60].

Pathways that promote the responsiveness of lung cancer cells to HDIs have been previously investigated. When tested in A549, PC14, FK228, a lung ADC cell line that is remarkably more resilient, HDIs blocked the Akt-mediated signalling pathway in the A549 cells but not in the resistant PC14 cells [61]. In another study of A549 cells, TSA was found to be pro-apoptotic, as evidenced by the downregulation of the antiapoptotic Bcl-2 protein, 
the upregulation of the pro-apoptotic Bax protein, and caspase activation [62]. On the other hand, in an analysis of the SCLC cell lines H69 and H526, the HDI FR901228 prompted caspase-dependent apoptosis via the mitochondrial pathway instead of the death receptor pathway [63].

HDAC inhibition causes acetylation not only of histones but also transcription factors such as p53, GATA-1, and estrogen receptor-alpha [64]. TSA-induced acetylation of histones $\mathrm{H} 3$ and $\mathrm{H} 4$ in lung cancer cells resulted in the re-expression of a number of TSGs, such as TGFBR2, SATB1, C/EBP alpha, MYO18B, and DAPK [65]. Zhong et al. discovered over 200 genes highly expressed by TSA treatment, using high-throughput gene expression microarrays coupled with pharmacologic inhibition of DNA methylation and histone deacetylation in NSCLC [66]. Some of these genes (NRIP3, CYLD, CD9, ATF3, and OXTR) verify the role of histone deacetylation in their silencing. More details on the effect of histone modification in lung cancer were covered in previous reviews [67].

HDIs (e.g., TSA and SAHA) exert a number of histone- and HDAC-independent functions [68]. In addition, the link of TSA to inflammatory pathways is intricate. TSA treatment was reported to upregulate cyclooxygenase-2 (COX-2) and CXCL12 in mouse macrophages and to downregulate proinflammatory genes encoding TNF- $\alpha$, IL-12p40, IL-6, endothelin 1, and the chemokines CCL2/monocyte chemotactic protein-1 (MCP-1) and CCL17 [49]. These findings indicate that individual HDIs have interconnected mechanisms of action on both deacetylation and non-histone pathways, which mandate further evaluation.

\subsubsection{Histone Deacetylases Inhibitors (HDIs) in Clinical Use}

Based on their structure, HDIs are classified into six groups [69]. A few HDIs have been shown to strengthen the cytotoxic effects of radiation by inhibiting DNA repair and enabling apoptosis in human NSCLC cells, having a significant synergism of action with conventional NSCLC chemotherapeutic agents [69]. Several HDIs are already being tested in clinical trials for the treatment of NSCLC patients.

Clinical data for HDI monotherapy in NSCLC are limited due to the small number of NSCLC patients in many trials. In particular, the outcomes in advanced, solid tumours have been underwhelming. While these agents are well tolerated, the best response is typically a stable disease, with rates ranging from 15 to $75 \%$ based on clinical context and the HDI evaluated [56]. An overview of clinical studies on HDIs as monotherapy and combinatorial therapy is presented in Table 1. While the existing information suggests that current HDIs are doubtful to supply a substantial benefit to NSCLC patients as monotherapy, they may be useful in combination with other agents. Vorinostat demonstrated the ability to enhance the response rate to first-line carboplatin and paclitaxel therapy in advanced NSCLC, but no survival benefit was observed [70]. In advanced chemo-refractory NSCLC, the introduction of entinostat to erlotinib presented no overall benefit compared to erlotinib alone, yet appeared to enhance survival in a subgroup of patients with high tumour E-cadherin levels at diagnosis [70,71].

Table 1. Histone-modification-based epigenetic therapy in clinical trials for NSCLC.

\begin{tabular}{|c|c|c|c|c|c|}
\hline Drug & $\begin{array}{c}\text { Target/ } \\
\text { Mechanism of Action }\end{array}$ & Phase of Trial & $\begin{array}{l}\text { Number of } \\
\text { Patients }\end{array}$ & Outcomes & $\begin{array}{c}\text { Clinical Trial } \\
\text { Identifier/ } \\
\text { Reference }\end{array}$ \\
\hline \multicolumn{6}{|c|}{ Histone Deacetylase Inhibitors } \\
\hline \multirow{3}{*}{ Vorinostat } & \multirow{3}{*}{$\begin{array}{l}\text { Prevents enzymatic activities of } \\
\text { class I and II HDACs, elicits cell } \\
\text { arrest, differentiation, and/or } \\
\text { apoptosis, antiproliferative, } \\
\text { G1/G2 cell cycle arrest, } \\
\text { disrupts VEGF signalling }\end{array}$} & Phase I & $\begin{array}{l}2 \mathrm{NSCLC} / \\
73 \text { patients }\end{array}$ & $\begin{array}{c}\mathrm{CR}=1, \mathrm{PR}=3, \\
\text { unconfirmed } \mathrm{PR}=2, \text { linear } \\
\text { pharmacokinetics with } \\
\text { good bioavailability }\end{array}$ & NCT00045006 [72] \\
\hline & & Phase II & 16 patients & $\mathrm{SD}=8, \mathrm{PR}=1, \mathrm{PD}=3$ & NCT00565227 [73] \\
\hline & & Phase II & 8 patients & $\begin{array}{l}\text { SD }(3.7 \text { months })=8 \\
\text { OS }=7.1 \text { months }\end{array}$ & NCT00126451 [74] \\
\hline
\end{tabular}


Table 1. Cont.

\begin{tabular}{|c|c|c|c|c|c|}
\hline Drug & $\begin{array}{c}\text { Target/ } \\
\text { Mechanism of Action }\end{array}$ & Phase of Trial & $\begin{array}{l}\text { Number of } \\
\text { Patients }\end{array}$ & Outcomes & $\begin{array}{c}\text { Clinical Trial } \\
\text { Identifier/ } \\
\text { Reference }\end{array}$ \\
\hline \multicolumn{6}{|c|}{ Histone Deacetylase Inhibitors } \\
\hline Romidepsin & $\begin{array}{l}\text { Triggers p21 expression, } \mathrm{H} 4 \\
\text { acetylation, shift gene signature } \\
\text { to normal epithelia }\end{array}$ & Phase II & $\begin{array}{l}19 \text { Lung } \\
\text { Cancer } \\
\text { patients }\end{array}$ & Transient SD = 9 & NCT00020202 [75] \\
\hline Pivanex & $\begin{array}{l}\text { Induces tumour cell } \\
\text { differentiation and/or } \\
\text { apoptosis }\end{array}$ & Phase II & $\begin{array}{l}47 \text { refractory } \\
\text { NSCLC } \\
\text { patients }\end{array}$ & $\begin{array}{c}\mathrm{PR}=6.4 \% \\
\mathrm{SD}(>12 \text { weeks })=30 \%, \\
\mathrm{MS}=6.2 \text { months1 year } \\
\text { survival rate }=26 \%\end{array}$ & [76] \\
\hline Cl-994 & $\begin{array}{l}\text { Inhibits histone deacetylation, } \\
\text { G1-S phase cell arrest }\end{array}$ & Phase I & $\begin{array}{l}53 \text { solid } \\
\text { tumours }\end{array}$ & $\begin{aligned} \mathrm{PR}= & 1 \text { heavily-pre-treated } \\
& \text { NSCLC patient } \\
\mathrm{SD}= & 3(1 \text { NSCLC patient })\end{aligned}$ & [77] \\
\hline \multicolumn{6}{|c|}{ Combination therapy } \\
\hline $\begin{array}{l}\text { Vorinostat + } \\
\text { Carboplatin } \\
\text { /Paclitaxel }\end{array}$ & - & Phase I & $\begin{array}{l}28 \text { advanced } \\
\text { solid tumour } \\
\text { patients }\end{array}$ & $\begin{array}{c}\mathrm{PR}=11(10 \text { NSCLC), } \mathrm{SD}=7 \\
\text { Linear Pharmacokinetics }\end{array}$ & [78] \\
\hline $\begin{array}{l}\text { Vorinostat + } \\
\text { Carboplatin/ } \\
\text { Paclitaxel }\end{array}$ & $\begin{array}{l}\text { Enhances the anti-cancer effects } \\
\text { of platinum compounds and } \\
\text { taxanes }\end{array}$ & Phase II & $\begin{array}{l}94 \text { advanced } \\
\text { (stage IIIB or } \\
\text { IV NSCLC } \\
\text { patients) }\end{array}$ & $\begin{array}{l}\text { Enhanced response rate } \\
\qquad \begin{array}{c}(34 \%) \\
\text { OS }=13 \text { months }\end{array}\end{array}$ & NCT01413750 [70] \\
\hline $\begin{array}{l}\text { Vorinostat }+ \\
\text { Bortezomib }\end{array}$ & $\begin{array}{l}\text { Combined induction } \\
\text { proteasome and histone } \\
\text { deacetylase inhibition }\end{array}$ & Phase I & 21 patients & Tumour necrosis (30\%) & [79] \\
\hline $\begin{array}{l}\text { Vorinostat }+ \\
\text { Sorafenib }\end{array}$ & - & Phase I & $\begin{array}{l}17 \text { patients } \\
\text { with advanced } \\
\text { solid tumours }\end{array}$ & $\begin{array}{l}\text { Unconfirmed PR }=2 \\
(1 \text { NSCLC patient })\end{array}$ & [80] \\
\hline $\begin{array}{l}\text { Vorinostat }+ \\
\text { Erlotinib }\end{array}$ & - & Phase I/II & $\begin{array}{l}33 \text { advanced } \\
\text { NSCLC EGFR } \\
\text { mutant } \\
\text { patients }\end{array}$ & $\begin{array}{l}\text { PFS }=8 \text { weeks } \\
\text { OS }=10.3 \text { months }\end{array}$ & NCT00503971 [81] \\
\hline $\begin{array}{l}\text { Panobinostat }+ \\
\text { Erlotinib }\end{array}$ & - & Phase I & $\begin{array}{l}35 \text { NSCLC/ } \\
42 \text { patients } \\
\text { with advanced } \\
\text { tumours }\end{array}$ & $\begin{array}{l}\text { Disease control rate }=54 \%, \\
\text { NSCLC PR }=3, \mathrm{SD}=3 \\
\text { PFS }=4.7 \text { months, OS }=41 \\
\text { months, (EGFR mutation) }\end{array}$ & NCT00738751 [82] \\
\hline $\begin{array}{c}\text { Entinostat }+ \\
\text { Erlotinib }\end{array}$ & - & Phase II & $\begin{array}{l}132 \text { stage IIIB } \\
\text { and IV NSCLC } \\
\text { patients }\end{array}$ & $\begin{array}{l}\text { Longer OS ( } 9.4 \text { months) in } \\
\text { high E-cadherin patients }\end{array}$ & NCT00602030 [71] \\
\hline $\begin{array}{l}\text { Pivanex }+ \\
\text { Docetaxel }\end{array}$ & $\begin{array}{l}\text { Synergistic action for growth } \\
\text { inhibition of NSCLC cell lines } \\
\text { in vitro and for improved } \\
\text { survival in animal models }\end{array}$ & $\begin{array}{l}\text { Phase I } \\
\text { Phase IIb }\end{array}$ & $\begin{array}{l}12 \text { patients } \\
225 \text { patients }\end{array}$ & Results not published & NCT00073385 \\
\hline $\begin{array}{c}\text { Cl-994 + } \\
\text { Gemcitabine }\end{array}$ & - & Phase II & $\begin{array}{l}26 \text { NSCLC/ } \\
174 \text { patients }\end{array}$ & $\begin{array}{c}\mathrm{PR}=8, \mathrm{OR}=12 \%, \mathrm{MS}=194 \\
\text { days }\end{array}$ & NCT00005093 [83] \\
\hline $\begin{array}{l}\text { Cl-994 + } \\
\text { Carboplatin + } \\
\text { Paclitaxel }\end{array}$ & - & Phase I & $\begin{array}{l}30 \text { patients } \\
\text { with advanced } \\
\text { solid tumours }\end{array}$ & $\begin{array}{c}\mathrm{H} 3 \text { acetylation levels } \\
<1.5 \text {-fold times } \\
\text { baseline }=\mathrm{PD}, \mathrm{H} 3 \\
\text { acetylation levels } \geq 1.5 \text {-fold } \\
\text { times baseline }=\mathrm{Clinical} \\
\text { response } / \mathrm{SD}, \mathrm{PR}=5 \text { ( } 3 \\
\text { NSCLC) }\end{array}$ & [84] \\
\hline $\begin{array}{c}\text { Azacitidine }+ \\
\text { Entinostat }\end{array}$ & $\begin{array}{l}\text { Inhibition of promoter } \\
\text { methylation }\end{array}$ & $\mathrm{I} / \mathrm{II}$ & $\begin{array}{l}45 \text { advanced, } \\
\text { refractory } \\
\text { NSCLC }\end{array}$ & $\begin{array}{c}\text { MS }=6.4 \text { months }, C R=1 \\
P R=1\end{array}$ & NCT00387465 [85] \\
\hline $\begin{array}{l}\text { Decitabine }+ \\
\text { valproic acid }\end{array}$ & $\begin{array}{l}\text { Inhibitors of DNA methylation } \\
\text { and histone deacetylases }\end{array}$ & I & $\begin{array}{l}8 \text { patients with } \\
\text { advanced } \\
\text { NSCLC with } \\
\text { prior } \\
\text { chemotherapy }\end{array}$ & $\mathrm{SD}=1$ & NCT00084981 [86] \\
\hline
\end{tabular}


Table 1. Cont.

\begin{tabular}{|c|c|c|c|c|c|}
\hline Drug & $\begin{array}{c}\text { Target/ } \\
\text { Mechanism of Action }\end{array}$ & Phase of Trial & $\begin{array}{l}\text { Number of } \\
\text { Patients }\end{array}$ & Outcomes & $\begin{array}{l}\text { Clinical Trial } \\
\text { Identifier/ } \\
\text { Reference }\end{array}$ \\
\hline $\begin{array}{l}\text { Decitabine }+ \\
\text { vorinostat }\end{array}$ & $\begin{array}{l}\text { Inhibitors of DNA methylation } \\
\text { and histone deacetylases }\end{array}$ & I & $\begin{array}{l}2 \text { patients with } \\
\text { NSCLC/ } \\
44 \text { with } \\
\text { advanced } \\
\text { tumours }\end{array}$ & $\mathrm{SD}=29 \%$ & NCT00275080 [85] \\
\hline $\begin{array}{c}\text { Azacitidine + } \\
\text { sodium } \\
\text { phenylbutyrate }\end{array}$ & $\begin{array}{l}\text { Inhibitors of DNA methylation } \\
\text { and histone deacetylases }\end{array}$ & I & $\begin{array}{c}1 \text { NSCLC/ } \\
27 \text { refractory } \\
\text { Solid Tumours }\end{array}$ & $\mathrm{SD}=1, \mathrm{PD}=26$ & NCT00005639 [87] \\
\hline $\begin{array}{c}\text { Hydralazine+ } \\
\text { magnesium } \\
\text { valproate }\end{array}$ & $\begin{array}{c}\text { Reduction in global DNA } \\
\text { methylation, histone } \\
\text { deacetylase activity, and } \\
\text { promoter demethylation were } \\
\text { observed }\end{array}$ & II & $\begin{array}{c}1 \text { NSCLC/ } \\
17 \text { refractory } \\
\text { solid tumours }\end{array}$ & $\mathrm{PR}=4, \mathrm{SD}=8$ & NCT00404508 [88] \\
\hline
\end{tabular}

CR: complete response, PR: partial response, SD: stable disease, PD: progressive disease, MS: median survival, OS: overall survival, PFS progression-free survival.

\subsubsection{Suberoylanilide Hydroxamic Acid (SAHA, Vorinostat)}

Vorinostat is a member of the hydroxamic acid group, which is the most diverse class of inhibitors with increased affinity for HDAC and has been shown to suppress both class I and II HDACs. At sub-micromolar concentrations, vorinostat prevents the enzymatic activity of HDAC1, HDAC2, and HDAC3 (class I) and HDAC6 (class II) [89]. Vorinostat (Figure 3) is a polar-planar compound of second generation that elicits cell arrest, differentiation, and/or apoptosis in a variety of transformed cells [90]. Vorinostat also demonstrated antiproliferative and pro-apoptotic effects in a variety of mouse xenografts and cancer cells, which include prostate, bladder, and breast carcinoma, as well as myeloma [91].

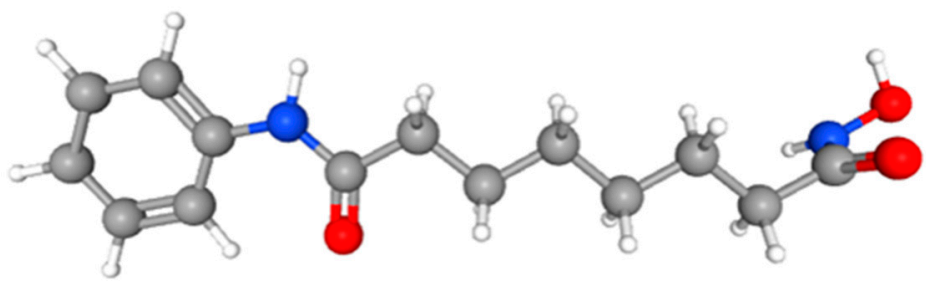

Figure 3. Chemical Structure of Vorinostat [92].

Vorinostat can also initiate G1/G2 cell-cycle arrest in a cell-dependent and dosedependent manner, as well as disrupt vascular endothelial growth factor (VEGF) signalling, implying that vorinostat might also hinder tumour neovascularization (Figure 4) [93]. Numerous studies on the action of vorinostat in conjunction with cytotoxic agents targeting chromatin DNA (such as etoposide, camptothecin, cisplatin, doxorubicin, 5-fluorouracil, and cyclophosphamide) have revealed synergistic and additive function in a wide range of cultured human transformed cell lines [94]. The effect of p53 gene condition on the interaction of vorinostat and carboplatin (a DNA targeting agent) across several NSCLC cell lines has been researched. Vorinostat increased carboplatin-induced cytotoxicity in NSCLC cells with wild-type p53, but not in cells lacking p53, implying the interference of a p53-dependent pathway. As a result, the addition of vorinostat may facilitate a decrease in the conventional carboplatin dose while optimising the overall therapeutic index [95]. 


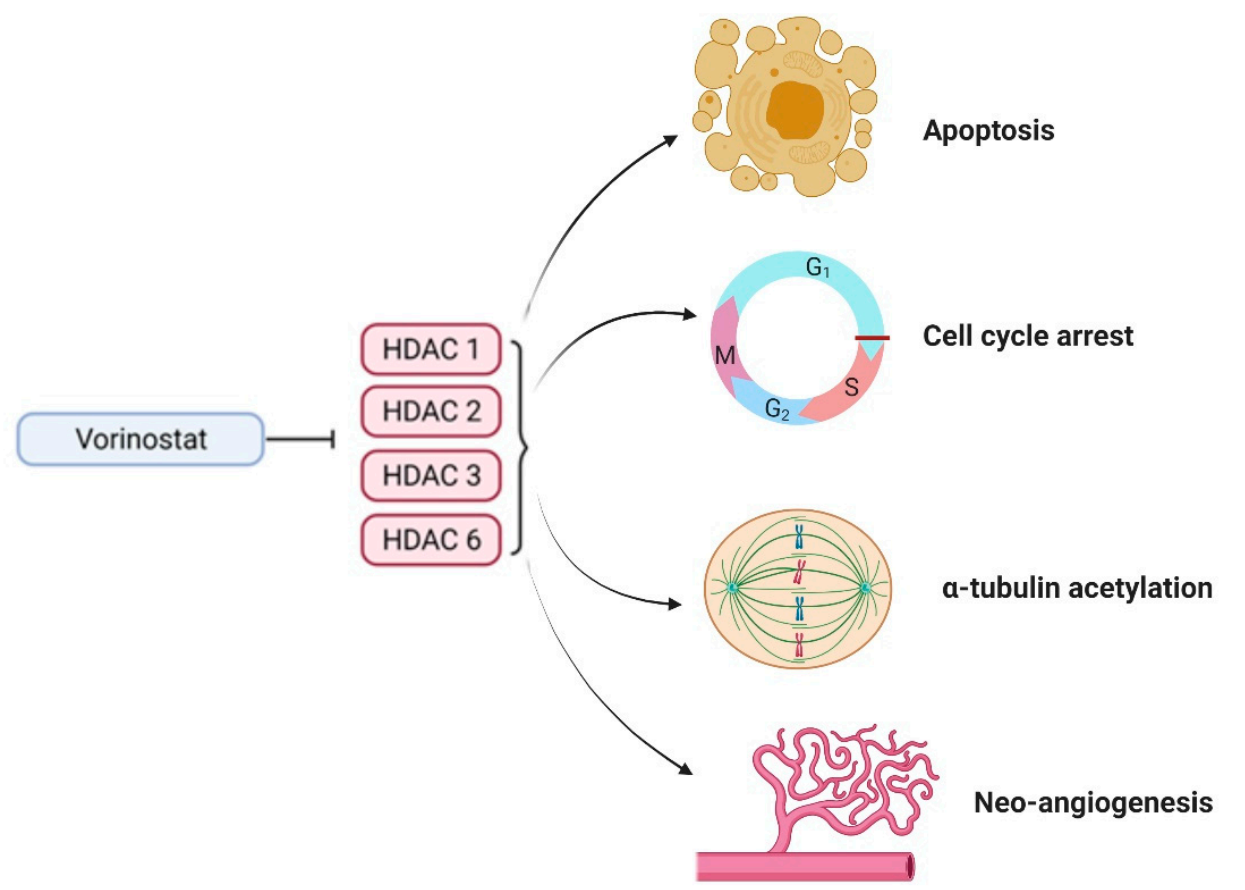

Figure 4. Multiple mechanisms of action of vorinostat in NSCLC.

Interestingly, the acetylation status of both tubulin and tubulin-associated proteins has been shown to regulate microtubule dynamics, implying that HDIs may interact favourably with taxanes to stop microtubule formation and initiate apoptosis [96]. HDAC6 exhibited the control alpha-tubulin deacetylation, implying that inhibiting HDAC6 with vorinostat might stabilize microtubules [96]. Because paclitaxel was shown to preferentially attach to stabilized microtubules, earlier administration of vorinostat may increase the effects of paclitaxel. Furthermore, the vorinostat ability to trigger G2/M cell-cycle accumulation and the increased sensitivity of $\mathrm{G} 2 / \mathrm{M}$ cells to paclitaxel supports the idea that vorinostat may potentiate paclitaxel's anti-tumour activity [97].

\subsection{Modifiers of Histone Methylation}

Inhibitors of methyl-transferases and demethylases exert anti-cancer effects against several solid tumours, including NSCLC [98]. KDM6A has a controversial role in NSCLC. It is a histone demethylase that antagonizes TGF- $\beta$ induced epithelial-mesenchymal transition [99]. KDM6A loss leads to a better sensitivity to EZH2 inhibitors, denoting that patients with NSCLC with a specific histone methylation pattern may benefit from specific epigenetic modifying therapy [100]. Tumour heterogeneity represents a key phenomenon in most cancers. More than a decade ago, Sharma et al. consistently identified a small subset of reversibly "EGFR inhibitor-tolerant" cells, acquiring their resistance through an IGF-1mediated signalling. Such resistance could be overcome through epigenetic manipulation, including pharmacological inhibition of the histone demethylase KDM5A/RBP2/JARID1A and reduced H3K4me2/me3 acetylation. Such "drug-tolerant cells" (later on known as cancer stem cells) with their distorted chromatin were extremely sensitive to the HDI effect [98].

A number of histone methylation inhibitors are under investigation in clinical trials $[98,101]$. Previous studies linked LSD1 aberrations with multiple malignancies, and the most promising results of LSD1 inhibitors were observed in acute myeloid leukaemia and SCLC [102], with GSK-2879552 and RG6016 representing a promising novel epigenetic approach for SCLC. Patients with NSCLC were considered a subset of recruited patients "with solid tumours" in those trials (e.g., NCT02082977). 


\subsection{Combination Therapy in Lung Cancer Using Histone Modifying Agents}

\subsubsection{Preclinical Combination Therapy}

Two new HDIs (ST2782 and ST3595) are synergized with taxanes, which operate by stabilizing microtubules in the spindle machinery and disrupting mitosis. In different cancer cell lines, including the NSCLC cells H460 and A549, combination therapy was preceded by an escalation in growth inhibition, apoptosis, and cell cycle delay at the G2/Mtransition. This could be due to the beneficial influence of acetylation on microtubular stabilization [103]. HDIs also resulted in thymidylate synthase downregulation, an enzyme involved in the folate cycle and a goal of cytostatic agents such as pemetrexed. Pemetrexed resistance is associated with increased thymidylate synthase levels. Numerous NSCLC cell lines exhibited a synergistic effect on growth inhibition and apoptosis if treated consecutively with pemetrexed and ITF2357, a pan-HDI. The findings were verified in xenograft models obtained from the H1650 adenocarcinoma cell line [104]. The HDI romidepsin was able to improve erlotinib anti-tumour effect in nine NSCLC lines with varying histology and mutation conditions, including EGFR-, KRAS-mutant, and wild type cell lines, with a decrease in tumour load in NCI-H1299 xenograft models [105]. HDAC inhibition, plus entinostat (MS-275), re-sensitized TKI-refractory NSCLC cell lines to gefitinib, most likely by recovering E-cadherin expression [106].

Panobinostat, a pan-HDI, not only made TKI-resistant A549 cells susceptible to erlotinib's antineoplastic action, but it also increased mono-, di-, and trimethylation of histone H3 lysine 4 (H3K4), indicating an intermodulation between HDI and LSD1 [107]. Moreover, panobinostat was able to prime NSCLC cell lines for the distinguishing effect of all-trans retinoic acid (ATRA) [108], and incorporating ATRA with the novel HDIs SL142 or SL325 repressed colony initiation, mediated apoptosis via Bax expression, and elevated caspase-3 activity in NSCLC cell lines [109]. The HDI (and anti-convulsant) sodium valproate also improved the anti-tumoural impact of cisplatinum-vinorelbine-based chemoradiation in NSCLC cell lines [110]. TSA also was able to radio sensitize NSCLC cell lines by initiating apoptosis and G2/M-cell-cycle arrest [111].

When combined with other agents, HDIs have a more pronounced overall impact. Vorinostat was shown to be effective in advanced lung cancer when coupled with carboplatin and paclitaxel [112]. In NSCLC cells, a combination of TSA and etoposide inflicted apoptotic cell death. Nutritional factors genistein and carotene, when combined with TSA, improved the cell growth arrest impact in A549 NSCLC cells [113]. The addition of low-dose vorinostat to 5-FU treatment increased drug-mediated cytotoxicity and contributed to synergistic implications, particularly in 5-FU-resistant NSCLC cells. Vorinostat could resolve 5-FU resistance by inhibiting thymidylate synthase expression and increasing p21waf1/cip1 expression through histone acetylation at its promoter. This was the first evidence that vorinostat increased 5-FU sensitivity in lung cancer cells by modulating 5-FU metabolism, and it will help future clinical trials of coupled chemotherapy and vorinostat in patients with NSCLC [114].

Millward et al. examined advanced solid tumours, including NSCLC cells, with vorinostat and marizomib, a novel bicyclic proteasome inhibitor, and discovered a heavily synergistic anti-tumour effect [115]. Despite the fact that no responses were observed using "Response Evaluation Criteria in Solid Tumours" (RECIST) criteria, over $60 \%$ of patients under evaluation had stable disease, with $39 \%$ showing reduction of the tumour size [115]. Combined therapy of vorinostat and arsenic trioxide enhances in vitro and in vivo H1299 NSCLC cell death [116]. Furthermore, combining suboptimal doses of sulindac, a nonsteroidal anti-inflammatory drug, with vorinostat resulted in growth inhibition of A549 human NSCLC cells, primarily through increased mitochondrial membrane potential collapse, cytochrome c release, and caspase induction [117]. Table 1 summarizes some currently underway clinical trials for the treatment of lung cancer with hypomethylating agents and HDIs [15]. Furthermore, the modification of histone methylation has the potential to improve the efficacy of chemotherapeutic agents as a combination therapy in lung cancer. Protein arginine methyltransferase 5 (PRMT5), for example, is highly 
expressed in lung ADC and is implicated in tumourigenesis. In ADC, the combination of PRMT5 inhibitor, arginine methyltransferase inhibitor 1 (AMI-1), and cisplatin resulted in anti-tumour activity by substantially decreasing cell viability and initiating apoptosis. Furthermore, this combination had no effect on the survival of normal bronchial epithelial cells [118].

\subsubsection{Clinical Studies of Combined Therapies with Histone Modifiers}

Jones et al. demonstrated that HDAC inhibition with vorinostat, coupled with proteasome inhibition with bortezomib preceded by surgical procedure, was a viable treatment strategy after performing a phase I study with 21 NSCLC patients [79]. Another phase I study investigated combined vorinostat with sorafenib (a multiple kinase inhibitor) in 17 patients with various cancers, including three with NSCLC, of whom one had a single case of grade $\mathrm{V}$ haemoptysis and another had a coronary incident. [80]. Panobinostat with erlotinib was well tolerated in a phase 1 trial in 33 patients with NSCLC, with dose-limiting toxicities emerging in two patients (nausea and prolonged QTc) that resolved without intervention. In a phase I/II study with 33 NSCLC EGFR-mutant patients who had progressed following erlotinib treatment, vorinostat combined with erlotinib only inhibited growth in 28 percent of the patients at 12 weeks following treatment [82].

In a phase II trial of 132 stage III and IV NSCLC patients who had progressed after pretreatment (one or two previous chemotherapy or chemo-radiotherapy regimens), entinostat in combination with the TKI, erlotinib, had no benefit on the sample population. Yet, compared to erlotinib alone, patients with high E-cadherin levels at recruitment had a longer OS [71] Ramalingam et al. involved 94 patients with advanced NSCLC in a randomly selected, double-blind, placebo-controlled phase II trial evaluating cisplatin/paclitaxel combined with vorinostat or a placebo. The combination therapy was advantageous in terms of response rate, but not in terms of median progression-free survival (PFS) or OS [70]. Although results are limited by the occurrence of adverse effects, it is required to develop epigenetic modifiers with safer profiles and to select the subset of patients who may benefit from such a combination of therapies.

\subsection{Combinatory Epigenetic Therapy}

The discovery that HDACs play a role in TSG silencing in cancer supports the hypothesis that combining DNA methyltransferase (DNMT) and HDAC inhibition could result in improved or maintained TSG reactivation. This hypothesis is supported by preclinical data. Cameron et al. illustrated that the combination of decitabine and TSA reactivated silenced TSGs in colon and leukaemia cell lines [119], displaying that the functional correlation between DNA methylation and histone deacetylation in gene silencing might be manipulated pharmaceutically. Briefly after, in vitro studies revealed additive or synergistic inhibition of DNA production, loss of clonogenicity, and activation of apoptosis in NSCLC cell lines medicated with decitabine and an HDI (phenylbutyrate, depsipeptide, or TSA) [120]. Furthermore, combining decitabine and phenylbutyrate was shown to synergistically suppress the progression of lung lesions in mice after exposure to the carcinogen nicotine-derived nitrosamine ketone (NNK) [121].

A combination of azacitidine and entinostat was tried in patients with NSCLC, with some promising outcomes (phase I/II). Clinical efficacy was observed for a relatively long duration (one complete response for 14-month duration). In a search of a correlative biomarker, there was a higher response rate and improvement in OS in the "methylation signature"-positive patients compared to patients with a negative signature. Promotor methylation status was tested through liquid biopsy (circulating DNA) from patients on day 0 and day 29 (after one cycle of therapy) [85].

\subsection{Combination Therapy of Histone Modifiers and Immune Checkpoint Inhibitors}

Immune checkpoint inhibitors (ICIs) have emerged as promising agents for the treatment of several types of cancer. As they rely on the immunogenicity of the tumours, 
combining them with epigenetic modifiers is an active field of research. As previously demonstrated, a cross talk and overlap exist between methylation and histone modification in the context of NSCLC. Intriguingly, treatment of tumour cells with DNMT inhibitors can stimulate the transcription of the constitutively silenced endogenous retrovirus (ERVs) [122], thus forming double-stranded RNAs in the cytoplasm [123], the ligand of the retinoic acid inducible gene I-like receptors (RLR) [70,124]. The RLR family is considered a group of innate immune sensors, and its activation initiates signalling cascades leading to interferon production by $\mathrm{CD} 8+\mathrm{T}$ cells, initiating an anti-tumour immune response [125]. Furthermore, epigenetic modifying agents mediate over-expression of tumour antigens (e.g., cancer testis antigens), increasing immunogenicity [126]. It is obvious that the combination of ICIs with epigenetic modifiers may be a promising strategy in the treatment of solid tumours.

In a recent study, several novel dual inhibitors of HDAC and heat-shock protein 90 (HSP90) were investigated in A549 and H1975 (NSCLC EGFR-resistant) cell lines. Interestingly, two of the tested compounds significantly reduce the PD-L1 expression of IFN- $\gamma$-treated H1975, referring to the promising role of histone modifiers in enhancing the effect of immunotherapy [127].

Combining HDIs with ICIs was investigated following a study that initially evaluated dual epigenetic modulation with entinostat and azacitidine, which did not result in a desirable anti-tumour response in patients with NSCLC. However, a patient subgroup proceeded to receive the anti-PD-1, nivolumab. Out of six patients, five showed a PFS of 6 months following the immunotherapy, a significant outcome in patients who had previously progressed on an ICI $[85,128]$. Epigenetic modification has primed the tumour to the action of the immunotherapy. An ongoing phase II trial is testing azacitidine and entinostat with concurrent nivolumab in patients with metastatic NSCLC, in immunotherapy-naïve versus immunotherapy-resistant patients (NCT01928576).

Furthermore, clinical trials of EZH2 inhibitors, combined with the PD-1 inhibitor "pembrolizumab" or the CTLA-4 inhibitor "ipilimumab", are under trial in advanced solid tumours (NCT03854474 and NCT03525795). In addition, tumour-associated antigens expressed in NSCLC include melanoma-associated antigen A3 (MAGEA3) and mucinous glycoprotein-1 (MUC1). MAGEA3 and MUC1 vaccines have both shown a potential effect and are undergoing testing in phase II and phase III trials [129].

\section{Conclusions and Future Direction}

Despite the fact that epigenetic studies in cancer, including histone modifications, started a few decades ago, the clinical application of histone modifying agents is still in its early stages and is not yet fully endorsed by the results of large-scale clinical trials. However, the intricate aspects of the cancer epigenome have highlighted tumour heterogeneity and the fact that cancer cell mutations are, by far, not the only initiators and drivers of carcinogenesis, but instead, the effects of those mutations are tightly controlled and directed by the epigenetic signature, which in turn is affected by many environmental factors.

Epigenetic modifiers are unlikely to enter into clinical practice in medical oncology as a standalone monotherapy. Instead, such medications can be combined with classic conventional anti-cancer medications, targeted therapies, or immune checkpoint inhibitors. The concerted action of combined medications should be selected for specific patient subsets who are likely to benefit from such therapies. Clinical trials showed that the adverse effects of such combination therapies are critically affecting the therapeutic outcomes, despite the relatively safe profile of epigenetic modifiers. Further research is required to appropriately place the epigenetic modifiers in the treatment algorithm of non-small cell lung cancer.

Author Contributions: Conceptualization, K.B. and M.S.-A.; writing, A.A.-A., K.B. and R.K.R.; writing-review and editing, K.B., M.S.-A., and Q.H.; visualization, R.K.R. and M.S.-A. All authors have read and agreed to the published version of the manuscript.

Funding: K.B. and M.S.-A. were funded by the MBRU-Al-Mahmeed Research Award 2019 (ALM1914). 
Institutional Review Board Statement: Not applicable.

Informed Consent Statement: Not applicable.

Data Availability Statement: Not applicable.

Acknowledgments: The authors acknowledge the support of the University of Sharjah and the MBRU-Al-Mahmeed Award.

Conflicts of Interest: The authors declare no conflict of interest.

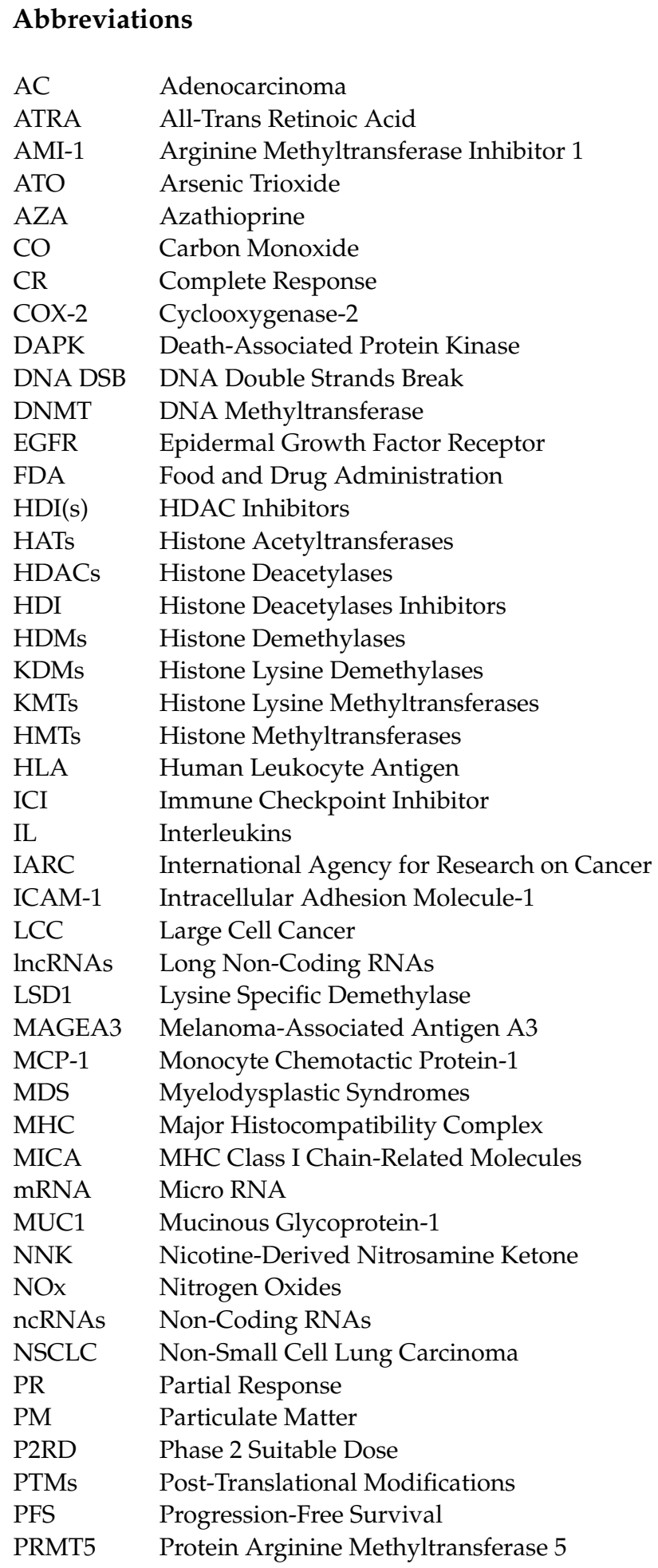




$\begin{array}{ll}\text { ROS } & \text { Reactive Oxygen Species } \\ \text { RFS } & \text { Relapse-Free Survival } \\ \text { RECIST } & \text { Response Evaluation Criteria in Solid Tumours } \\ \text { SCLC } & \text { Small Cell Lung Cancer } \\ \text { SCC } & \text { Squamous Cell Carcinoma } \\ \text { SAHA/Vorinostat } & \text { Suberoylanilide Hydroxamic Acid } \\ \mathrm{SO}_{2} & \text { Sulphur Dioxide } \\ \text { TSA } & \text { Trichostatin A } \\ \text { TSG } & \text { Tumour Suppression Genes } \\ \text { TKI } & \text { Tyrosine Kinase Inhibitor } \\ \text { VEGF } & \text { Vascular Endothelial Growth Factor } \\ \text { abb } & \text { ddd } \\ \text { AC } & \text { Adenocarcinoma }\end{array}$

\section{References}

1. Jemal, A.; Center, M.M.; DeSantis, C.; Ward, E.M. Global patterns of cancer incidence and mortality rates and trends. Cancer Epidemiol. Biomark. Prev. 2010, 19, 1893-1907. [CrossRef] [PubMed]

2. Kalemkerian, G.P.; Loo, B.W.; Akerley, W.; Attia, A.; Bassetti, M.; Boumber, Y.; Decker, R.; Dobelbower, M.C.; Dowlati, A.; Downey, R.J.; et al. NCCN Guidelines Insights: Small Cell Lung Cancer, Version 2.2018. J. Natl. Compr. Cancer Netw. 2018, 16, 1171-1182. [CrossRef] [PubMed]

3. Osmani, L.; Askin, F.; Gabrielson, E.; Li, Q.K. Current WHO guidelines and the critical role of immunohistochemical markers in the subclassification of non-small cell lung carcinoma (NSCLC): Moving from targeted therapy to immunotherapy. Semin. Cancer Biol. 2018, 52 Pt 1, 103-109. [CrossRef] [PubMed]

4. Travis, W.D.; Brambilla, E.; Noguchi, M.; Nicholson, A.G.; Geisinger, K.R.; Yatabe, Y.; Beer, D.G.; Powell, C.A.; Riely, G.J.; Van Schil, P.E.; et al. International Association for the Study of Lung Cancer/American Thoracic Society/European Respiratory Society International Multidisciplinary Classification of Lung Adenocarcinoma. J. Thorac. Oncol. 2011, 6, 244-285. [CrossRef]

5. Gu, Y.; Zhang, J.; Zhou, Z.; Liu, D.; Zhu, H.; Wen, J.; Xu, X.; Chen, T.; Fan, M. Metastasis Patterns and Prognosis of Octogenarians with NSCLC: A Population-based Study. Aging Dis. 2020, 11, 82-92. [CrossRef]

6. Siegel, R.L.; Miller, K.D.; Fuchs, H.E.; Jemal, A. Cancer Statistics, 2021. CA Cancer J. Clin. 2021, 71, 7-33. [CrossRef]

7. Travis, W.D.; Brambilla, E.; Müller-Hermelink, H.K. WHO Classification of tumours: Tumours of the lung, pleura, thymus and heart. Pathol. Genet. 2004.

8. Cantone, L.; Nordio, F.; Hou, L.; Apostoli, P.; Bonzini, M.; Tarantini, L.; Angelici, L.; Bollati, V.; Zanobetti, A.; Schwartz, J.; et al. Inhalable metal-rich air particles and histone H3K4 dimethylation and H3K9 acetylation in a cross-sectional study of steel workers. Envrion. Health Perspect. 2011, 119, 964-969. [CrossRef]

9. Zhou, X.; Li, Q.; Arita, A.; Sun, H.; Costa, M. Effects of nickel, chromate, and arsenite on histone 3 lysine methylation. Toxicol. Appl. Pharmacol. 2009, 236, 78-84. [CrossRef]

10. Santarpia, M.; Aguilar, A.; Chaib, I.; Cardona, A.F.; Fancelli, S.; Laguia, F.; Bracht, J.W.P.; Cao, P.; Molina-Vila, M.A.; Karachaliou, N.; et al. Non-Small-Cell Lung Cancer Signaling Pathways, Metabolism, and PD-1/PD-L1 Antibodies. Cancers 2020, $12,1475$. [CrossRef]

11. Weinstein, I.B.; Joe, A. Oncogene Addiction. Cancer Res. 2008, 68, 3077-3080. [CrossRef]

12. Adcock, I.M.; Caramori, G.; Barnes, P.J. Chronic Obstructive Pulmonary Disease and Lung Cancer. New Mol. Insights 2011, 81, 265-284.

13. Shahadin, M.S.; Mutalib, N.S.A.; Latif, M.T.; Greene, C.M.; Hassan, T. Challenges and future direction of molecular research in air pollution-related lung cancers. Lung Cancer 2018, 118, 69-75. [CrossRef]

14. Karpinets, T.V.; Foy, B.D. Tumorigenesis: The adaptation of mammalian cells to sustained stress environment by epigenetic alterations and succeeding matched mutations. Carcinogenesis 2005, 26, 1323-1334. [CrossRef]

15. Ansari, J.; Shackelford, R.E.; El-Osta, H. Epigenetics in non-small cell lung cancer: From basics to therapeutics. Transl. Lung Cancer Res. 2016, 5, 155-171. [CrossRef]

16. Peschansky, V.J.; Wahlestedt, C. Non-coding RNAs as direct and indirect modulators of epigenetic regulation. Epigenetics 2014, 9 , 3-12. [CrossRef]

17. Wang, Y.X.S.Y.; Li, X. Genome-wide DNA methylation profiling reveals novel epigenetic signatures in squamous cell lung cancer. BMC Genom. 2017, 18, 901-2017.

18. Jin, N.; George, T.L.; Otterson, G.A.; Verschraegen, C.; Wen, H.; Carbone, D.; Herman, J.; Bertino, E.M.; He, K. Advances in epigenetic therapeutics with focus on solid tumors. Clin. Epigenetics 2021, 13, 83. [CrossRef]

19. Mamdani, H.; Jalal, S.I. Histone Deacetylase Inhibition in Non-small Cell Lung Cancer: Hype or Hope? Front. Cell Dev. Biol. 2020, 8, 582370. [CrossRef]

20. Sterlacci, W.; Tzankov, A.; Veits, L.; Zelger, B.; Bihl, M.P.; Foerster, A.; Augustin, F.; Fiegl, M.; Savic, S. A Comprehensive Analysis of p16 Expression, Gene Status, and Promoter Hypermethylation In Surgically Resected Non-small Cell Lung Carcinomas. J. Thorac. Oncol. 2011, 6, 1649-1657. [CrossRef] 
21. Audia, J.E.; Campbell, R.M. Histone Modifications and Cancer. Cold Spring Harb. Perspect. Biol. 2016, 8, a019521. [CrossRef] [PubMed]

22. Bowman, G.D.; Poirier, M.G. Post-Translational Modifications of Histones That Influence Nucleosome Dynamics. Chem. Rev. 2015, 115, 2274-2295. [CrossRef] [PubMed]

23. Berger, S.L. The complex language of chromatin regulation during transcription. Nature 2007, 447, 407-412. [CrossRef] [PubMed]

24. Wang, L.; Zhao, Z.; Ozark, P.A.; Fantini, D.; Marshall, S.A.; Rendleman, E.J.; Cozzolino, K.A.; Louis, N.; He, X.; Morgan, M.A.; et al. Resetting the epigenetic balance of Polycomb and COMPASS function at enhancers for cancer therapy. Nat. Med. 2018, 24, 758-769. [CrossRef]

25. Strachan, T.; Read, A. Human Molecular Genetics; Garland Science: New York, NY, USA, 2004; Volume 3.

26. Dokmanovic, M.; Marks, P.A. Prospects: Histone deacetylase inhibitors. J. Cell. Biochem. 2005, 96, 293-304. [CrossRef]

27. Grunstein, M. Histone acetylation in chromatin structure and transcription. Nature 1197, 389, 349-352. [CrossRef]

28. Miyanaga, A.; Gemma, A.; Noro, R.; Kataoka, K.; Matsuda, K.; Nara, M.; Okano, T.; Seike, M.; Yoshimura, A.; Kawakami, A.; et al. Antitumor activity of histone deacetylase inhibitors in non-small cell lung cancer cells: Development of a molecular predictive model. Mol. Cancer Ther. 2008, 7, 1923-1930. [CrossRef]

29. Marks, P. Discovery and development of SAHA as an anticancer agent. Oncogen 2007, 26, 1351-1356. [CrossRef]

30. Riggs, M.G.; Whittaker, R.G.; Neumann, J.R.; Ingram, V.M. n-Butyrate causes histone modification in HeLa and Friend erythroleukaemia cells. Nature 1977, 268, 462-464. [CrossRef]

31. Müller, M.M.; Muir, T.W. Histones: At the Crossroads of Peptide and Protein Chemistry. Chem. Rev. 2015, 115, 2296-2349. [CrossRef]

32. Yi, X.; Jiang, X.J.; Li, X.Y.; Jiang, D.S. Histone methyltransferases: Novel targets for tumor and developmental defects. Am. J. Transl. Res. 2015, 7, 2159-2175.

33. D'Oto, A.; Tian, Q.; Davidoff, A.M.; Yang, J. Histone demethylases and their roles in cancer epigenetics. J. Med. Oncol. Ther. 2016, 1, 34-40. [CrossRef]

34. Van Rechem, C.; Whetstine, J.R. Examining the impact of gene variants on histone lysine methylation. Biochim. Biophys. Acta 2014, 1839, 1463-1476. [CrossRef]

35. Mohammad, H.P. A DNA Hypomethylation signature predicts antitumor activity of LSD1 inhibitors in SCLC. Cancer Cell 2015, 28, 57-69. [CrossRef]

36. Takashina, T.; Kinoshita, I.; Kikuchi, J.; Shimizu, Y.; Sakakibara-Konishi, J.; Oizumi, S.; Nishimura, M.; Dosaka-Akita, H. Combined inhibition of EZH2 and histone deacetylases as a potential epigenetic therapy for non-small-cell lung cancer cells. Cancer Sci. 2016, 107, 955-962. [CrossRef]

37. Mazur, P.K.; Reynoird, N.; Khatri, P.; Jansen, P.W.T.C.; Wilkinson, A.W.; Liu, S.; Barbash, O.; van Aller, G.S.; Huddleston, M.; Dhanak, D.; et al. SMYD3 links lysine methylation of MAP3K2 to Ras-driven cancer. Nature 2014, 10, 283-287. [CrossRef]

38. Li, J.; Tao, X.; Shen, J.; Liu, L.; Zhao, Q.; Ma, Y.; Tao, Z.; Zhang, Y.; Ding, B.; Xia, Z. The molecular landscape of histone lysine methyltransferases and demethylases in non-small cell lung cancer. Int. J. Med. Sci. 2019, 16, 922-930. [CrossRef]

39. Fraga, M.F.; Ballestar, E.; Villar-Garea, A.; Boix-Chornet, M.; Espada, J.; Schotta, G.; Bonaldi, T.; Haydon, C.; Ropero, S.; Petrie, K.; et al. Loss of acetylation at Lys16 and trimethylation at Lys20 of histone H4 is a common hallmark of human cancer. Nat. Genet. 2005, 37, 391-400. [CrossRef]

40. van den Broeck, A.; Brambilla, E.; Moro-Sibilot, D.; Lantuejoul, S.; Brambilla, C.; Eymin, B.; Khochbin, S.; Gazzeri, S. Loss of histone H4K20 trimethylation occurs in preneoplasia and influences prognosis of non-small cell lung cancer. Clin. Cancer Res. 2008, 14, 7237-7245. [CrossRef]

41. Barlesi, F.; Giaccone, G.; Gallegos-Ruiz, M.I.; Loundou, A.; Span, S.W.; Kruyt, P.L.A.; Rodriguez, J. Global histone modifications predict prognosis of resected non small-cell lung cancer. J. Clin. Oncol. 2007, 25, 4358-4364. [CrossRef]

42. Seligson, D.B.; Horvath, S.; Brian, M.A.M.; Mah, V.; Yu, H.; Tze, S.; Wang, Q.; Chia, D.; Goodglick, L.; Kurdistani, S.K. Global levels of histone modifications predict prognosis in different cancers. Am. J. Pathol. 2009, 174, 1619-1628. [CrossRef]

43. Kurdistani, S.K. Histone modifications in cancer biology and prognosis. Prog. Drug Res. 2011, 67, 91-106.

44. Esteller, M. Epigenetics provides a new generation of oncogenes and tumour-suppressor genes. Br. J. Cancer 2006, 94, 179-183. [CrossRef]

45. Esteller, M. Cancer epigenomics: DNA methylomes and histone-modification maps. Nat. Rev. Genet. 2007, 8, 286-298. [CrossRef]

46. Sasaki, H.; Moriyama, S.; Nakashima, Y.; Kobayashi, Y.; Kiriyama, M.; Fukai, I.; Yamakawa, Y.; Fujii, Y. Histone deacetylase 1 mRNA expression in lung cancer. Lung Cancer 2004, 46, 171-178. [CrossRef]

47. Osada, H.; Tatematsu, Y.; Saito, H.; Yatabe, Y.; Mitsudomi, T.; Takahashi, T. Reduced expression of class II histone deacetylase genes is associated with poor prognosis in lung cancer patients. Int. J. Cancer 2004, 112, 26-32. [CrossRef]

48. Bartling, B.; Hofmann, H.; Boettger, T.; Hansen, G.; Burdach, S.; Silber, R.; Simma, A. Comparative application of antibody and gene array for expression profiling in human squamous cell lung carcinoma. Lung Cancer 2005, 49, 145-154. [CrossRef]

49. Sonke, J.J.; Belderbos, J. Adaptive radiotherapy for lung cancer. Semin. Radiat. Oncol. 2010, 20, 94-106. [CrossRef]

50. Jones, G.S.; Baldwin, D.R. Recent advances in the management of lung cancer. Clin. Med. 2018, 18, s41-s46. [CrossRef]

51. Forde, P.M.; Brahmer, J.R.; Kelly, R.J. New Strategies in Lung Cancer: Epigenetic Therapy for Non-Small Cell Lung Cancer. Clin. Cancer Res. 2014, 20, 2244-2248. [CrossRef] 
52. Moon, D.H.; Kwon, S.O.; Kim, W.J.; Hong, Y. Identification of Serial DNA Methylation Changes in the Blood Samples of Patients with Lung Cancer. Tuberc. Respir. Dis. 2019, 82, 126-132. [CrossRef] [PubMed]

53. Yoshida, M.; Kijima, M.; Akita, M.; Beppu, T. Potent and specific inhibition of mammalian histone deacetylase both in vivo and in vitro by trichostatin A. J. Biol. Chem. 1990, 265, 17174-17179. [CrossRef]

54. Warrener, R.; Beamish, H.; Burgess, A.; Waterhouse, N.J.; Giles, N.; Fairlie, D.P.; Gabrielli, B. Tumor cell-selective cytotoxicity by targeting cell cycle checkpoints. FASEB J. 2003, 17, 1-21. [CrossRef] [PubMed]

55. Bolden, J.E.; Peart, M.J.; Johnstone, R.W. Anticancer activities of histone deacetylase inhibitors. Nat. Rev. Drug Discov. 2006, 5, 769-784. [CrossRef]

56. Ramalingam, S.S.; Kummar, S.; Sarantopoulos, J.; Shibata, S.; LoRusso, P.; Yerk, M.; Holleran, J.; Lin, Y.; Beumer, J.; Harvey, R.D.; et al. Phase I study of vorinostat in patients with advanced solid tumors and hepatic dysfunction: A national cancer institute organ dysfunction working group study. J. Clin. Oncol. 2010, 28, 4507-4512. [CrossRef]

57. Imre, G.; Gekeler, V.; Leja, A.; Beckers, T.; Boehm, M. Histone deacetylase inhibitors suppress the inducibility of nuclear factor kappaB by tumor necrosis factor-alpha receptor-1 down regulation. Cancer Res. 2006, 66, 5409-5418. [CrossRef]

58. Mukhopadhyay, N.; Gordon, G.; Maulik, G.; Doerre, G.; Liu, B.C.; Bueno, R.; Sugarbaker, D.; Jaklitsch, M. Histone deacetylation is directly involved in desilencing the expression of the catalytic subunit of telomerase in normal lung fibroblast. J. Cell. Mol. Med. 2005, 9, 662-669. [CrossRef]

59. Bártová, E.; Pacherník, J.; Harničarová, A.; Kovarik, A.; Kovaríková, M.; Hofmanová, J.; Skalníková, M.; Kozubek, M.; Kozubek, S. Nuclear levels and patterns of histone H3 modification and HP1 proteins after inhibition of histone deacetylases. J. Cell Sci. 2005, 118, 5035-5046. [CrossRef]

60. El-Khoury, V.; Gomez, D.; Liautaud-Roger, F.; Trussardi-Régnier, A.; Dufer, J. Effects of the histone deacetylaseinhibitor trichostatin A on nuclear texture and c-jungene expression in drug-sensitive and drug-resistant human H69 lung carcinoma cells. Cytom. $A$ 2004, 62, 109-417. [CrossRef]

61. Kodani, M.; Igishi, T.; Matsumoto, S.; Chikumi, H.; Shigeoka, Y.; Nakanishi, H.; Morita, M.; Yasuda, K.; Hitsuda, Y.; Shimizu, E. Suppression of phosphatidylinositol 3-kinase/Akt signaling pathway is a determinant of the sensitivity to a novel histone deacetylase inhibitor, FK228, in lung adenocarcinoma cells. Oncol. Rep. 2005, 13, 477-483. [CrossRef]

62. Choi, Y.H. Induction of apoptosis by trichostatin A, a histone deacetylase inhibitor, is associated with inhibitionof cyclooxygenase2 activity in human non-small cell lung cancer cells. Int. J. Oncol. 2005, 27, 473-479.

63. Kitazono, M.; Bates, S.; Fok, P.; Fojo, T.; Blagosklonny, M. V The histone deacetylase inhibitor FR901228 (desipeptide) restores expression and function of pseudo-null p53. Cancer Biol. Ther. 2002, 1, 665-668. [CrossRef]

64. Eckschlager, T.; Plch, J.; Stiborova, M.; Hrabeta, J. Histone Deacetylase Inhibitors as Anticancer Drugs. Int. J. Mol. Sci. 2017, 18, 1414. [CrossRef]

65. Halder, S.K.; Cho, Y.; Datta, A.; Anumanthan, G.; Ham, A.L.; Carbone, D.P.; Datta, P.K. Elucidating the mechanism of regulation of transforming growth factor \& Type II receptor expression in human lung cancer cell lines. Neoplasia 2011, 13, 912-922. [CrossRef]

66. Zhong, S.; Fields, C.R.; Su, N.; Pan, Y.; Robertson, K.D. Pharmacologic inhibition of epigenetic modifications, coupled with gene expression profiling, reveals novel targets of aberrant DNA methylation and histone deacetylation in lung cancer. Oncogene 2007, 26, 2621-2634. [CrossRef]

67. Brzeziańska, E.; Dutkowska, A.; Antczak, A. The significance of epigenetic alterations in lung carcinogenesis. Mol. Biol. Rep. 2012, 40, 309-325. [CrossRef]

68. Weiss, U.; Möller, M.; Husseini, S.A.; Manderscheid, C.; Häusler, J.; Geisslinger, G.; Niederberger, E. Inhibition of HDAC Enzymes Contributes to Differential Expression of Pro-Inflammatory Proteins in the TLR-4 Signaling Cascade. Int. J. Mol. Sci. 2020, 21, 8943. [CrossRef]

69. Cuneo, K.C.; Fu, A.; Osusky, K.; Huamani, J.; Hallahan, D.E.; Geng, L. Histone deacetylase inhibitor NVP-LAQ824 sensitizes human nonsmall cell lung cancer to the cytotoxic effects of ionizing radiation. Anti-Cancer Drugs 2007, 18, 793-800. [CrossRef]

70. Ramalingam, S.S.; Maitland, M.L.; Frankel, P.; Argiris, A.E.; Koczywas, M.; Gitlitz, B.; Thomas, S.; Espinoza-Delgado, I.; Vokes, E.E.; Gandara, D.R.; et al. Carboplatin and paclitaxel in combination with either vorinostat or placebo for first-line therapy of advanced non-small-cell lung cancer. J. Clin. Oncol. 2010, 28, 56-62. [CrossRef]

71. Witta, S.E.; Jotte, R.M.; Konduri, K.; Neubauer, M.A.; Spira, A.I.; Ruxer, R.L.; Varella-Garcia, M.; Bunn, P.A., Jr.; Hirsch, F.R. Randomized phase II trial of erlotinib with and without entinostat in patients with advanced non_small-cell lung cancer who progressed on prior chemotherapy. J. Clin. Oncol. 2012, 30, 2248-2255. [CrossRef]

72. Kelly, W.K.; O'Connor, O.A.; Krug, M.L. Phase I study of an oral histone deacetylase inhibitor, suberoylanilide hydroxamic acid, in patients with advanced cancer. J. Clin. Oncol. 2005, 23, 3923-3931. [CrossRef]

73. Vansteenkiste, J.; Van Cutsem, E.; Dumez, H.; Chen, C.; Ricker, J.L.; Randolph, S.S.; Schöffski, P. Early phase II trial of oral vorinostat in relapsed or refractory breast, colorectal, or non-small cell lung cancer. Investig. New Drugs 2008, 26, 483-488. [CrossRef]

74. Traynor, A.M.; Dubey, S.; Eickhoff, J.C.; Kolesar, J.M.; Schell, K.; Huie, M.S.; Groteluschen, D.L.; Marcotte, S.M.; Hallahan, C.M.; Weeks, H.R.; et al. Vorinostat (NSC\# 701852) in Patients with Relapsed Non-small Cell Lung Cancer: A Wisconsin Oncology Network Phase II Study. J. Thorac. Oncol. 2009, 4, 522-526. [CrossRef]

75. Schrump, D.S.; Fischette, M.R.; Nguyen, D.M.; Zhao, M. Clinical and molecular responses in lung cancer patients receiving romidepsin. Clin. Cancer Res. 2008, 14, 188-198. [CrossRef] 
76. Reid, T.; Valone, F.; Lipera, W.; Irwin, D.; Paroly, W.; Natale, R.; Sreedharan, S.; Keer, H.; Lum, B.; Scappaticci, F.; et al. Phase II trial of the histone deacetylase inhibitor pivaloyloxymethyl butyrate (Pivanex, AN-9) in advanced non-small cell lung cancer. Lung Cancer 2004, 45, 381-386. [CrossRef]

77. Prakash, S.; Foster, B.J.; Meyer, M.; Wozniak, A.; Heilbrun, L.K.; Flaherty, L.; Zalupski, M.; Radulovic, L.; Valdivieso, M.; Lorusso, P.M. Chronic Oral Administration of CI-994: A Phase I Study. Investig. New Drugs 2001, 19, 1-11. [CrossRef]

78. Ramalingam, S.S.; Parise, R.A.; Ramananthan, R.K.; Lagattuta, T.F.; Musguire, L.A.; Stoller, R.G.; Potter, D.M.; Argiris, A.E.; Zwiebel, J.A.; Egorin, M.J.; et al. Phase I and Pharmacokinetic Study of Vorinostat, A Histone Deacetylase Inhibitor, in Combination with Carboplatin and Paclitaxel for Advanced Solid Malignancies. Clin. Cancer Res. 2007, 13, 3605-3610. [CrossRef]

79. Jones, D.R.; Moskaluk, C.A.; Gillenwater, H.H.; Petroni, G.R.; Burks, S.G.; Philips, J.; Rehm, P.K.; Olazagasti, J.; Kozower, B.D.; Bao, Y. Phase I Trial of Induction Histone Deacetylase and Proteasome Inhibition Followed by Surgery in Non-small Cell Lung Cancer. J. Thorac. Oncol. 2012, 7, 1683-1690. [CrossRef]

80. Dasari, A.; Gore, L.; Messersmith, W.A.; Diab, S.; Jimeno, A.; Weekes, C.D.; Lewis, K.D.; Drabkin, H.A.; Flaig, T.W.; Camidge, D.R. A phase I study of sorafenib and vorinostat in patients with advanced solid tumors with expanded cohorts in renal cell carcinoma and non-small cell lung cancer. Investig. New Drugs 2012, 31, 115-125. [CrossRef]

81. Reguart, N.; Rosell, R.; Cardenal, F.; Cardona, A.F.; Isla, D.; Palmero, R.; Moran, T.; Rolfo, C.; Pallarès, M.C.; Insa, A.; et al. Phase I/II trial of vorinostat (SAHA) and erlotinib for non-small cell lung cancer (NSCLC) patients with epidermal growth factor receptor (EGFR) mutations after erlotinib progression. Lung Cancer 2014, 84, 161-167. [CrossRef]

82. Gray, J.E.; Haura, E.; Chiappori, A.; Tanvetyanon, T.; Williams, C.C.; Pinder-Schenck, M.; Kish, J.A.; Kreahling, J.; Lush, R.; Neuger, A.; et al. A phase I, pharmacokinetic and pharmacodynamic study of panobinostat, an HDAC inhibitor, combined with erlotinib in patients with advanced aerodigestive tract tumors. Clin. Cancer Res. 2014, 20, 1644-1655. [CrossRef] [PubMed]

83. Richards, D.A.; Boehm, K.A.; Waterhouse, D.M.; Wagener, D.J.; Krishnamurthi, S.S.; Rosemurgy, A.; Grove, W.; Macdonald, K.; Gulyas, S.; Clark, M.; et al. Gemcitabine plus CI-994 offers no advantage over gemcitabine alone in the treatment of patients with advanced pancreatic cancer: Results of a phase II randomized, double-blind, placebo-controlled, multicenter study. Ann. Oncol. 2006, 17, 1096-1102. [CrossRef] [PubMed]

84. Pauer, L.R.; Olivares, J.; Cunningham, C.; Williams, A.; Grove, W.; Kraker, A.; Olson, S.; Nemunaitis, J. Phase I study of oral CI-994 in combination with carboplatin and paclitaxel in the treatment of patients with advancedsolid tumors. Cancer Investig. 2004, 22, 886-896. [CrossRef] [PubMed]

85. Juergens, R.A.; Wrangle, J.; Vendetti, F.P.; Murphy, S.C.; Zhao, M.; Coleman, B.; Sebree, R.; Rodgers, K.; Hooker, C.M.; Franco, N.; et al. Combination Epigenetic Therapy Has Efficacy in Patients with Refractory Advanced Non-Small Cell Lung Cancer. Cancer Discov. 2011, 1, 598-607. [CrossRef]

86. Chu, B.F.; Karpenko, M.J.; Liu, Z.; Aimiuwu, J.; Villalona-Calero, M.A.; Chan, K.K.; Grever, M.R.; Otterson, G.A. Phase I study of 5-aza-2'-deoxycytidine in combination with valproic acid in non-small-cell lung cancer. Cancer Chemother. Pharmacol. 2012, 71, 115-121. [CrossRef]

87. Lin, J.; Gilbert, J.; Rudek, M.A.; Zwiebel, J.A.; Gore, S.; Jiemjit, A.; Zhao, M.; Baker, S.; Ambinder, R.F.; Herman, J.G.; et al. A Phase I Dose-Finding Study of 5-Azacytidine in Combination with Sodium Phenylbutyrate in Patients with Refractory Solid Tumors. Clin. Cancer Res. 2009, 15, 6241-6249. [CrossRef]

88. Candelaria, M.; Gallardo-Rincón, D.; Arce, C.; Cetina, L.; Aguilar-Ponce, J.; Arrieta, O.; González-Fierro, A.; Chávez-Blanco, A.; de la Cruz-Hernández, E.; Camargo, M.; et al. A phase II study of epigenetic therapy with hydralazine and magnesium valproate to overcome chemotherapy resistance in refractory solid tumors. Ann. Oncol. 2007, 18, 1529-1538. [CrossRef]

89. Marks, P.; Rifkind, R.A.; Richon, V.M.; Breslow, R.; Miller, T.; Kelly, W.K. Histone deacetylases and cancer: Causes and therapies. Nat. Rev. Cancer 2001, 1, 194-202. [CrossRef]

90. Krämer, O.H.; Göttlicher, M.; Heinzel, T. Histone deacetylase as a therapeutic target. Trends Endocrinol. Metab. 2001, 12, 294-300. [CrossRef]

91. Mitsiades, N.; Mitsiades, C.S.; Richardson, P.G. Molecular sequelae of histone deacetylase inhibition in human malignant B cells. Blood 2003, 101, 4055-4062. [CrossRef]

92. Bolton, E.; Chen, J.; Kim, S.; Han, L.; He, S.; Shi, W.; Simonyan, V.; Sun, Y.; Thiessen, P.; Wang, J.; et al. PubChem3D: A new resource for scientists. J. Chemin. 2011, 3, 32. [CrossRef]

93. Deroanne, C.F.; Bonjean, K.; Servotte, S.; Devy, L.; Colige, A.; Clausse, N.; Blacher, S.; Verdin, E.; Foidart, J.; Nusgens, B.V.; et al. Histone deacetylase inhibitors as anti-angiogenic agents altering vascular endothelial growth factor signalling. Oncogene 2002, 17, 427-436. [CrossRef]

94. Marchion, D.C.; Bicaku, E.; Daud, A.I.; Richon, V.; Sullivan, D.M.; Munster, P.N. Sequence-specific potentiation of topoisomerase II inhibitors by the histone deacetylase inhibitor suberoylanilide hydroxamic acid. J. Cell. Biochem. 2004, 92, 223-237. [CrossRef]

95. Hershberger, P.; Owonikoko, T.K.; Ramalingam, S.; Belani, C.P. The effect of p53 gene status on the interaction of vorinostat (suberoylanilide hydroxamic acid-SAHA) with carboplatin in non-small cell lung cancer (NSCLC) cell lines. J. Clin. Oncol. 2007, 25, 10567. [CrossRef]

96. Zhang, Y.; Li, N.; Caron, C.; Matthias, G.; Hess, D.; Khochbin, S.; Matthias, P. HDAC-6 interacts with and deacetylates tubulin and microtubules in vivo. EMBO J. 2003, 22, 1168-1179. [CrossRef] 
97. Blagosklonny, M.V.; Robey, R.; Sackett, D.L.; Du, L.; Traganos, F.; Darzynkiewicz, Z.; Fojo, T.; Bates, S.E. Histone deacetylase inhibitors all induce p21 but differentially cause tubulin acetylation, mitotic arrest, and cytotoxicity. Mol. Cancer Ther. 2002, 1, 937-941.

98. Chen, Y.; Liu, X.; Li, Y.; Quan, C.; Zheng, L.; Huang, K. Lung Cancer Therapy Targeting Histone Methylation: Opportunities and Challenges. Comput. Struct. Biotechnol. J. 2018, 16, 211-223. [CrossRef]

99. Terashima, M.; Ishimura, A.; Wanna-Udom, S.; Suzuki, T. Epigenetic regulation of epithelial-mesenchymal transition by KDM6A histone demethylase in lung cancer cells. Biochem. Biophys. Res. Commun. 2017, 490, 1407-1413. [CrossRef]

100. Wu, Q.; Tian, Y.; Zhang, J.; Tong, X.; Huang, H.; Li, S.; Zhao, H.; Tang, Y.; Yuan, C.; Wang, K.; et al. In vivo CRISPR screening unveils histone demethylase UTX as an important epigenetic regulator in lung tumorigenesis. Proc. Natl. Acad. Sci. USA 2018, 115, E3978-E3986. [CrossRef]

101. McGrath, J.; Trojer, P. Targeting histone lysine methylation in cancer. Pharmacol. Ther. 2015, 150, 1-22. [CrossRef]

102. Przespolewski, A.; Wang, E.S. Inhibitors of LSD1 as a potential therapy for acute myeloid leukemia. Expert. Opin. Investig. Drugs 2016, 25, 771-780. [CrossRef]

103. Zuco, V.; De Cesare, M.; Cincinelli, R.; Nannei, R.; Pisano, C.; Zaffaroni, N.; Zunino, F. Synergistic Antitumor Effects of Novel HDAC Inhibitors and Paclitaxel In Vitro and In Vivo. PLoS ONE 2011, 6, e29085. [CrossRef]

104. del Bufalo, D.; Desideri, M.; de Luca, T.; di Martile, M.; Gabellini, C.; Monica, V.; Busso, S.; Eramo, A.; de Maria, R.; Milella, M.; et al. Histone deacetylase inhibition synergistically enhances pemetrexed cytotoxicity through induction of apoptosis and autophagy in non-small cell lung cancer. Mol. Cancer 2014, 13, 1-16. [CrossRef]

105. Zhang, W.; Peyton, M.; Xie, Y.; Soh, J.; Minna, J.D.; Gazdar, A.F.; Frenkel, E.P. Histone Deacetylase Inhibitor Romidepsin Enhances Anti-Tumor Effect of Erlotinib in Non-small Cell Lung Cancer (NSCLC). Cell Lines 2009, 4, 161-166. [CrossRef] [PubMed]

106. Witta, S.E.; Gemmill, R.M.; Hirsch, F.R.; Coldren, C.D.; Hedman, K.; Ravdel, L.; Helfrich, B.; Dziadziuszko, R.; Chan, D.C.; Sugita M.; et al. Restoring E-cadherin expression increases sensitivity to epidermal growth factor receptor inhibitors in lung cancer cell lines. Cancer Res. 2006, 66, 944-950. [CrossRef] [PubMed]

107. Greve, G.; Schiffmann, I.; Pfeifer, D.; Pantic, M.; Schüler, J.; Lübbert, M. The pan-HDAC inhibitor panobinostat acts as a sensitizer for erlotinib activity in EGFR-mutated and -wildtype non-small cell lung cancer cells. BMC Cancer 2015, 15, 1-10. [CrossRef] [PubMed]

108. Greve, G.; Schiffmann, I.; Lübbert, M. Epigenetic priming of non-small cell lung cancer cell lines to the antiproliferative and differentiating effects of all-trans retinoic acid. J. Cancer Res. Clin. Oncol. 2015, 141, 2171-2180. [CrossRef]

109. Han, S.; Fukazawa, T.; Yamatsuji, T.; Matsuoka, J.; Miyachi, H.; Maeda, Y.; Durbin, M.; Naomoto, Y. Anti-tumor effect in human lung cancer by a combination treatment of novel histone deacetylase inhibitors: SL142 or SL325 and retinoic acids. PLoS ONE 2010, 5, e13834. [CrossRef]

110. Gavrilov, V.; Lavrenkov, K.; Ariad, S. Sodium Valproate, a Histone Deacetylase Inhibitor, Enhances the Efficacy of Vinorelbine-Cisplatin- based Chemoradiation in Non-small Cell Lung Cancer Cells. Anticancer Res. 2014, 34, 6565-6572.

111. Zhang, F.; Zhang, T.; Teng, Z.; Zhang, R.; Wang, J.; Mei, Q. Sensitization to gamma-irradiation-induced cell cycle arrest and apoptosis by the histone deacetylase inhibitor trichostatin A in non-small cell lung cancer (NSCLC) cells. Cancer Biol. Ther. 2009, 8, 823-831. [CrossRef]

112. Vendetti, F.P.; Topper, M.; Huang, P.; Dobromilskaya, I.; Easwaran, H.; Wrangle, J.; Baylin, S.B.; Poirier, J.; Rudin, C.M. Evaluation of azacitidine and entinostat as sensitization agents to cytotoxic chemotherapy in preclinical models of non-small cell lung cancer. Oncotarget 2014, 6, 56-70. [CrossRef]

113. Shiau, R.; Chen, K.; Wen, Y.; Chuang, C.; Yeh, S. Genistein and beta-carotene enhance the growth-inhibitory effect of trichostatin A in A549 cells. Eur. J. Nutr. 2010, 49, 19-25. [CrossRef]

114. Komatsu, N.; Kawamata, N.; Takeuchi, S.; Yin, D.; Chien, W.; Miller, C.W.; Koeffler, H.P. SAHA, a HDAC inhibitor, has profound anti-growth activity against non-small cell lung cancer cells. Oncol. Rep. 2006, 15, 187-191. [CrossRef]

115. Millward, M.; Price, T.; Townsend, A.; Sweeney, C.; Spencer, A.; Sukumaran, S.; Longenecker, A.; Lee, L.; Lay, A.; Sharma, G.; et al. Phase 1 clinical trial of the novel proteasome inhibitor marizomib with the histone deacetylase inhibitor vorinostat in patients with melanoma, pancreatic and lung cancer based on in vitro assessments of the combination. Investig. New Drugs 2012, 30, 2303-2317. [CrossRef]

116. Chien, C.; Yao, J.; Chang, S.; Lee, P.; Lee, T. Enhanced suppression of tumor growth by concomitant treatment of human lung cancer cells with suberoylanilide hydroxamic acid and arsenic trioxide. Toxicol. Appl. Pharmacol. 2011, 257, 59-66. [CrossRef]

117. Seo, S.K.; Jin, H.O.; Lee, H.C.; Woo, S.H.; Kim, E.S. Combined effects of sulindac and suberoylanilide hydroxamic acid on apoptosis induction in human lung cancer cells. Mol. Pharmacol. 2008, 73, 1005-1012. [CrossRef]

118. Bajbouj, K.; Ramakrishnan, R.K.; Saber-Ayad, M.; Omar, H.A.; Sharif-Askari, N.S.; Shafarin, J.; Elmoselhi, A.B.; Ihmaid, A.; Ali, S.A.; Alalool, A.; et al. PRMT5 Selective Inhibitor Enhances Therapeutic Efficacy of Cisplatin in Lung Cancer Cells. Int. J. Mol. Sci. 2021, 22, 6131. [CrossRef]

119. Cameron, E.E.; Bachman, K.E.; Myöhänen, S.; Herman, J.G.; Baylin, S.B. Synergy of demethylation and histone deacetylase inhibition in the re-expression of genes silenced in cancer. Nat. Genet. 1999, 21, 103-107. [CrossRef]

120. Boivin, A.-J.; Momparler, L.F.; Hurtubise, A.; Momparler, R.L. Antineoplastic action of 5-aza-2'-deoxycytidine and phenylbutyrate on human lung carcinoma cells. Anti-Cancer Drugs 2002, 13, 869-874. [CrossRef] 
121. Belinsky, S.A.; Klinge, D.M.; Stidley, C.A.; Issa, J.P. Inhibition of DNA methylation and histone deacetylation prevents murine lung cancer. Cancer Res. 2003, 63, 7089-7093.

122. Lander, E.S.; Linton, L.M.; Birren, B.; Nusbaum, C.; Zody, M.C.; Baldwin, J.; Devon, K.; Dewar, K.; Doyle, M.; FitzHugh, W.; et al. Initial sequencing and analysis of the human genome. Nature 2001, 409, 860-921. [CrossRef]

123. Roulois, D.; Loo Yau, H.; Singhania, R.; Wang, Y.; Danesh, A.; Shen, S.Y.; Han, H.; Liang, G.; Jones, P.A.; Pugh, T.J.; et al. DNA-Demethylating Agents Target Colorectal Cancer Cells by Inducing Viral Mimicry by Endogenous Transcripts. Cell 2015, 162, 961-973. [CrossRef]

124. Yan, N.; Chen, Z.J. Intrinsic antiviral immunity. Nat. Immunol. 2012, 13, 214-222. [CrossRef]

125. Héninger, E.; Krueger, T.E.G.; Lang, J.M. Augmenting antitumor immune responses with epigenetic modifying agents. Front. Immunol. 2015, 6, 29. [CrossRef]

126. Karpf, A.R.; Jones, D.A. Reactivating the expression of methylation silenced genes in human cancer. Oncogene 2002, 21, 5496-5503. [CrossRef]

127. Mehndiratta, S.; Lin, M.-H.; Wu, Y.-W.; Chen, C.-H.; Wu, T.-Y.; Chuang, K.-H.; Chao, M.-W.; Chen, Y.-Y.; Pan, S.-L.; Chen, M.-C.; et al. N-alkyl-hydroxybenzoyl anilide hydroxamates as dual inhibitors of HDAC and HSP90, downregulating IFN- $\gamma$ induced PD-L1 expression. Eur. J. Med. Chem. 2020, 185, 111725. [CrossRef]

128. Banik, D.; Moufarrij, S.; Villagra, A. Immunoepigenetics Combination Therapies: An Overview of the Role of HDACs in Cancer Immunotherapy. Int. J. Mol. Sci. 2019, 20, 2241. [CrossRef]

129. Davies, M. New modalities of cancer treatment for NSCLC: Focus on immunotherapy. Cancer Manag. Res. 2014, 6, 63-75. [CrossRef] 